University of Rhode Island

DigitalCommons@URI

Open Access Master's Theses

1999

\title{
Adsorbtion of Total Petroleum Hydrocarbons Contaminated Water with Granular Activated Carbon
}

Adedeji O. Adeyoye

University of Rhode Island

Follow this and additional works at: https://digitalcommons.uri.edu/theses

\section{Recommended Citation}

Adeyoye, Adedeji O., "Adsorbtion of Total Petroleum Hydrocarbons Contaminated Water with Granular Activated Carbon" (1999). Open Access Master's Theses. Paper 873.

https://digitalcommons.uri.edu/theses/873

This Thesis is brought to you for free and open access by DigitalCommons@URI. It has been accepted for inclusion in Open Access Master's Theses by an authorized administrator of DigitalCommons@URI. For more information, please contact digitalcommons-group@uri.edu. 


\section{ADSORPTION OF TOTAL PETROLEUM HYDROCARBONS CONTAMINATED \\ WATER WITH \\ GRANULAR ACTIVATED CARBON}

BY

ADEDEJI O. ADEYOYE

A THESIS SUBMITTED IN PARTIAL FULFILLMENT OF THE REQUIREMENTS FOR THE DEGREE Of MASTER OF SCIENCE

IN

CIVIL AND ENVIRONMENTAL ENGINEERING

UNIVERSITY OF RHODE ISLAND

1999 
MASTER OF SCIENCE THESIS

$\mathrm{OF}$

ADEDEJI ADEYOYE

APPROVED

Thesis Committee

Major Professor

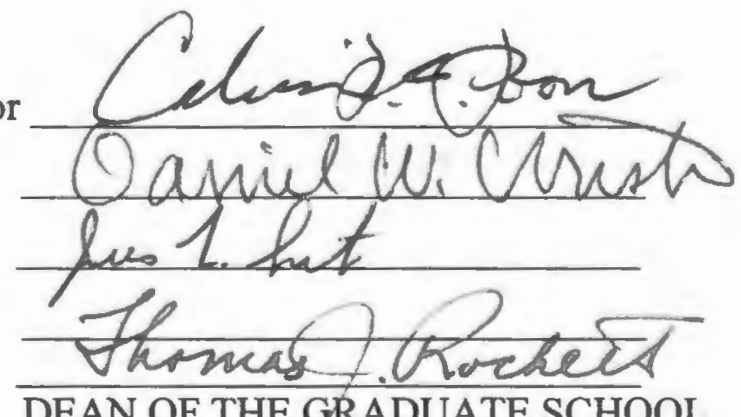

DEAN OF THE GRADUATE SCHOOL

UNIVERSITY OF RHODE ISLAND

1999 


\section{Abstract}

This study evaluated the effectiveness of granular activated carbon in treating hydrocarbons contaminated groundwater. Contaminated groundwater samples were obtained from the airfield refueling area of the former Davisville - Quonset Point Naval Complex at North Kingstown, R.I. Previous studies on the site showed the contaminants as a mixture of JP 5 and aviation fuel, but because of the changes that might have taken place within the constituents of the groundwater contaminants due to aging, volatilization, exposure, and interaction with the soils minerals and the groundwater, the contaminants are characterized as Total Petroleum Hydrocarbons(TPH).

This study conducted isotherm studies on the contaminated water using Granular Activated Carbon,(GAC) F- 400, Calgon Corp., Pittsburg, PA. Freundlich Isotherm parameters were obtained from the batch adsorption isothermal studies. The analyses of the breakthrough curves obtained from the experimental column tests provided the information needed to assess the most reasonable GAC adsorber volume for treating the contaminated water under this situation. This could serve as model for sizing a field scale carbon adsorber required for similar contaminants.

This study utilized granular activated carbon, (GAC) F-400, Calgon in treating 210 Liters of $7 \mathrm{mg} / \mathrm{L}, 324$ Liters of $6 \mathrm{mg} / \mathrm{L}$ and 360 Liters of $144 \mathrm{mg} / \mathrm{L}$ of aged fuel (TPH) contaminated water samples at flowrates of $0.5 \mathrm{~L} / \mathrm{min}, 0.6 \mathrm{~L} / \mathrm{min}$ and $0.75 \mathrm{~L} / \mathrm{min}$ respectively. 


\section{ACKNOWLEDGEMENTS}

First and foremost, I wish to thank the Almighty God without whom this work could not have been possible and for his magnificent gift of life.

I wish to express my appreciation to Department of Defense for the fellowship granted me. In particular I will like to thank Dr. Daniel W. Urish for his untiring supports.

I wish to thank the U.S Army Corps of Engineers, GZA Inc.,Providence, Rhode Island and Roy F. Weston Inc., Manchester, New Hampshire for making it possible to obtain samples for this study.

I also offer my thanks to my major professor, Dr. Calvin Poon for his unrelenting guidance and advice, and Dr. Jim Smith for his advice and encouragement.

I like to extend my thanks to the following people, whose assistance have been invaluable:

- Dr. Leon Thiem

- Todd Crawford

- Virginia Mulholland

Finally, I like to thank my family, and everybody who have contributed to the success of this project. 


\section{TABLE OF CONTENTS}

Page

LIST OF TABLES vi

LIST OF ILLUSTRATIONS

ABSTRACT

1.0 INTRODUCTION.

1.1 Conventional Remedial Technique................................................5

1.2 In- Situ Remedial Techniques................................................6

1.2.1 Air Stripping ..........................................................

1.2.2 Soil Vapor Extraction............................................... 7

1.2 .3 Soil Washing..........................................................

1.2.4 Electro-Osmosis.......................................................8

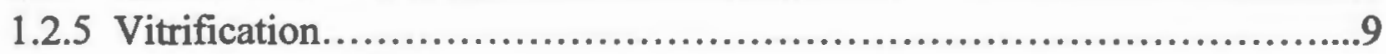

1.2.6 Solvent Extraction.................................................... 9

1.2.7 Supercritical Fluid Extraction.........................................10

1.2 .8 Bioremediation........................................................ 10

1.2.9 Carbon Adsorption................................................... 11

i. Carbon Selection..................................................... 12

ii. Adsorber Configuration...................................................

iii. Effects of Empty Bed Contact Time.........................................14

iv. Design of Activated Carbon System..........................................14

v. Column Design Using Scale-Up Approach...............................16

vi. Evaluation of Bed-depth Service Time (BDST) $\ldots \ldots \ldots \ldots \ldots \ldots \ldots \ldots \ldots \ldots \ldots . \ldots \ldots$

2.0 EXPERIMENTAL PROCEDURES \& ANALYTICAL METHODOLOGY.........22

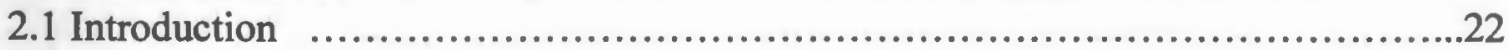

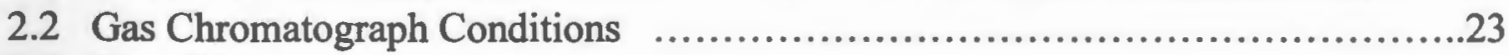

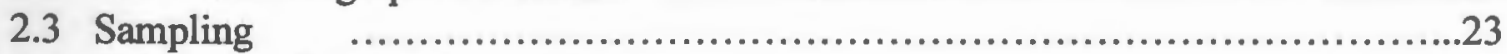

2.4 Calibration Standards..........................................................24

2.5 Methodology for Calibration Standards.........................................24

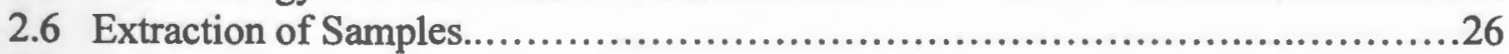

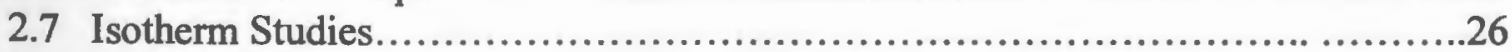

2.8 Grain Size Analysis of Calgon's Filtrasorb 400 ....................................28

2.9 Design and Operation of GAC Column ...............................................30 


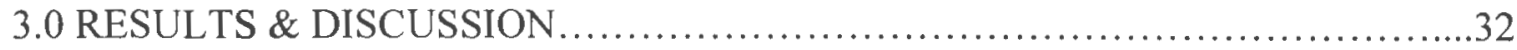

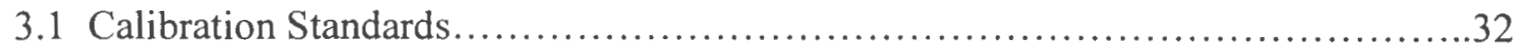

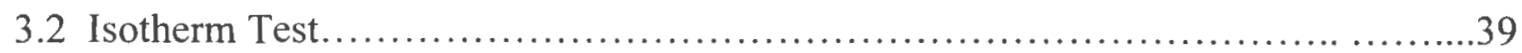

3.3 GAC Column System Experiment ..............................................40

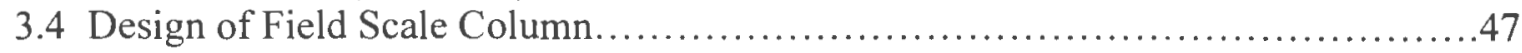

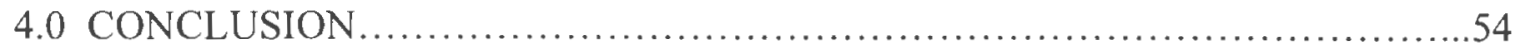

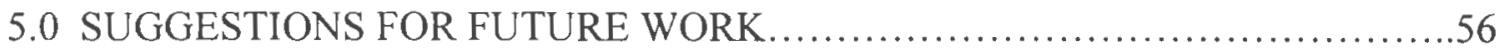

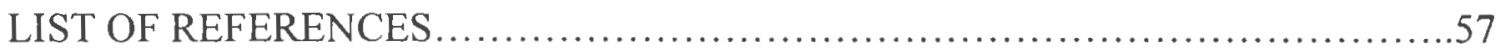
APPENDIXES
A. Individual Sample Fuel Mixture Composition Data for JP-5 ....................61

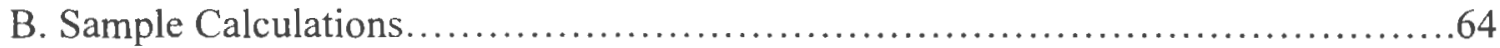

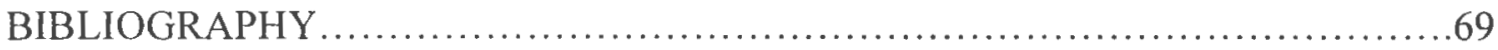




\section{LIST OF TABLES}

Table 2.1 - Distribution of Calgon's Filrasorb 400 grain sizes.......................28

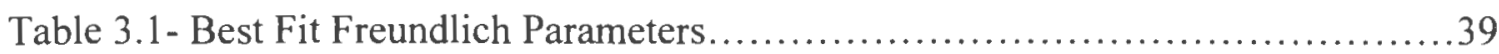

3.2- Summary data at TPH breakthrough point of $0.35 \mathrm{mg} / \mathrm{L}$ using Calgon's GAC in the experiment with concentration of $7 \mathrm{mg} / \mathrm{L} \ldots \ldots \ldots \ldots \ldots \ldots \ldots \ldots \ldots . \ldots \ldots \ldots$

3.3- Summary data at TPH breakthrough point of $0.3 \mathrm{mg} / \mathrm{L}$ using Calgon's GAC

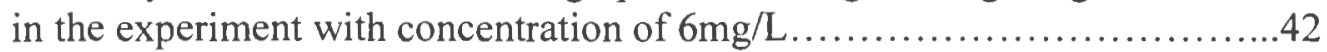

3.4- Summary data at TPH breakthrough point of $7.15 \mathrm{mg} / \mathrm{L}$ using Calgon's GAC

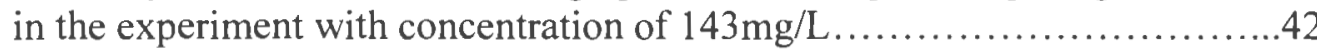

\section{LIST OF ILLUSTRATIONS}

Figure 1.1 - Map showing location of the Former Davisville-Quonset Point Naval Complex in the Davisville-Quonset Point area of N.Kingstown..............3

Figure 1.2- Map showing location of the product recovery wells on the contaminated site.............................................................. 4

Figure 1.3- Carbon adsorption breakthrough curve showing movement of Adsorption zone.

Figure 1.4- Laboratory Curves for Three Columns, each 2-inch diameter and $7.5 \mathrm{ft}$ deep........................................................... 18

Figure 1.5- Bed-Depth Service Time Curve.....................................20

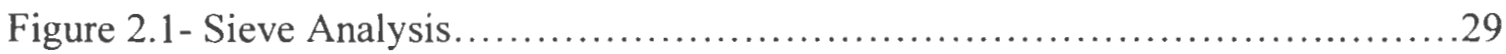

Figure 2.2- Calibration curve for Gilmont Flowmeter................................30

Figure 2.3- Component of Granular Activated Carbon Column System...................31

Figure 2.4-Photograph of Gas Chromatograph instruments used for the analysis in this experiment....................................................31

Figure 3.1- Chromatograms showing the resolved peaks for carbon disulfide.......... 33

3.2- Chromatogram for $520 \mathrm{ug} / \mathrm{mL}$ commercially available aviation fuel in carbon disulfide.................................................. 33

3.3- Chromatogram for $400 \mathrm{ug} / \mathrm{mL}$ commercially available JP 5 in carbon disulfide.............................................................34

3.4- Chromatogram for $200 \mathrm{ug} / \mathrm{mL}$ of mixture of commercially available aviation fuel and JP 5 in carbon disuifide..............................34

3.5- Chromatogram for $78 \mathrm{ug} / \mathrm{mL}$ of aged jet fuel (TPH) in carbon disulfide.... 35

3.6- Chromatogram for $186 \mathrm{ug} / \mathrm{mL}$ of aged jet fuel (TPH) in carbon disulfide.... 35

3.7- Chromatogram for $284 \mathrm{ug} / \mathrm{mL}$ of aged jet fuel (TPH) in carbon disulfide.....36

3.8- Chromatogram for $372 \mathrm{ug} / \mathrm{mL}$ of aged jet fuel (TPH) in carbon disulfide... .36 
3.9 - Chromatogram for $620 \mathrm{ug} / \mathrm{mL}$ of aged jet fuel (TPH) in carbon disulfide ...37

3.10- Chromatogran for $1.2 \mathrm{mg} / \mathrm{mL}$ of aged jet fuel (TPH) in carbon disulfide...37

3.11 - Chromatogram for $2.4 \mathrm{mg} / \mathrm{mL}$ of aged jet fuel (TPH) in carbon disulfide...38

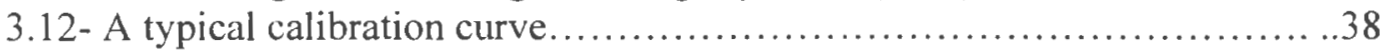

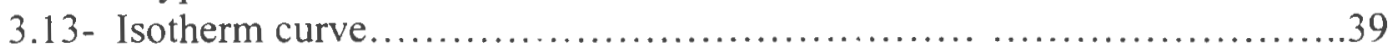

3.14- Laboratory Breakthrough Curve for the first column in the

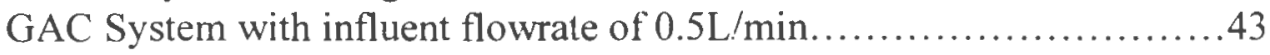

3.15- Breakthrough Curve for second column in the GAC System............ 43

3.16- Breakthrough Curves for the first and second columns in the GAC System......................................................... 44

3.17- Laboratory Breakthrough Curve for the first column in the GAC System with influent flowrate of $0.6 \mathrm{~L} / \mathrm{min}$

3.18- Laboratory Breakthrough Curve for the first column in the GAC System with influent flowrate of $0.75 \mathrm{~L} / \mathrm{min}$.

3.19- Laboratory Breakthrough Curve for the second column in the GAC System with influent flowrate of $0.75 \mathrm{~L} / \mathrm{min}$.

3.20- Laboratory Breakthrough Curve for the second column in the GAC System with influent flowrate of $0.75 \mathrm{~L} / \mathrm{min}$.

3.21- The projected/simulated breaktlurough curve for the first column with flowrate of $0.75 \mathrm{~L} / \mathrm{min}$.

3.22- The projected/simulated breakthrough curve for the second column

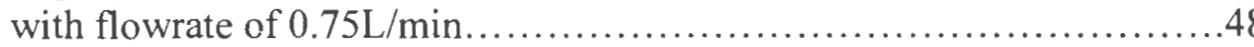

3.23- The projected/simulated breakthrough curve for the third column with flowrate of $0.75 \mathrm{~L} / \mathrm{min}$.

3.24- The projected/simulated breakthrough curve for the three columns with flowrate of $0.75 \mathrm{~L} / \mathrm{min}$.

3.25- The bed-depth Service Time curve for the three columns with the flowrate of $0.75 \mathrm{~L} / \mathrm{min}$. 


\section{INTRODUCTION}

Groundwater pollution is a universal problem often caused by anthropogenic activities. Studies by the U.S Environmental Protection Agency found that about $80 \%$ of the $1,400,000$ underground gasoline storage tanks in the United States were bare steel tanks lacking corrosion protection, and that about $35 \%$ of the tanks leaked at an average rate of 29L/day (Donaldson,1992). Osgood (1974) reported that for over a five year period there were more than 200 hydrocarbon spills in Pennsylvania alone. Widespread use of petroleum products, above ground spills at petrochemicals complexes, overfilling and leakage of underground storage tanks and pipelines, improper underground injection of liquids, leaching from landfills, as well as everyday operations at retail outlets have all contributed to the pollution of soil and groundwater. Groundwater which is the largest potential source of potable water is threatened by innumerable sources of pollution. This pollution has far reaching effects and the cost of groundwater decontamination is tremendous.

Granular Activated Carbon (GAC) has been widely used for water and wastewater treatment. It has proven to be an excellent adsorbent for a broad spectrum of organics. A number of granular activated carbons are commercially available; in this study Calgon Filtrasorb 400 (F-400) was chosen as the carbon of choice because of its proven track record in removing many organic chemicals of concern.

Many mathematical models have been developed to predict adsorption behavior in carbon systems, but the complexity of most systems require the imput of 
experimental data. Although adsorptive capacity can be evaluated by means of a laboratory test, there is no standard procedure for such tests and there are numerous pitfalls leading to erroneous results and misinterpretation of data.

Figures 1.1 and 1.2 show locations of the contaminated site in the DavisvilleQuonset Point and the product recovery wells respectively. The product recovery wells are designed to retain within them some of the contaminants. Wells which are labeled "PR" in Figure 1.2 are equipped with filter canisters "Petropore" by PJ Products Co. These automatically separate the contaminants from groundwater and contain the contaminants which are supposedly recovered at intervals by the monitoring staff. The "MPR" labeled wells in Figure 1.2 do not have filter canisters, the contaminants are separated from groundwater at the time of removal by the monitoring personnel. This study carried out three different GAC column experiments, the TPH contaminated waters used in these experiments were taken from product recovery wells (PR) \# 3,6,8 \&9, and manual product recovery wells (MPR) \# $10 \& 14$. These waters were mixed together and diluted with tap water accordingly, for the experiments. 


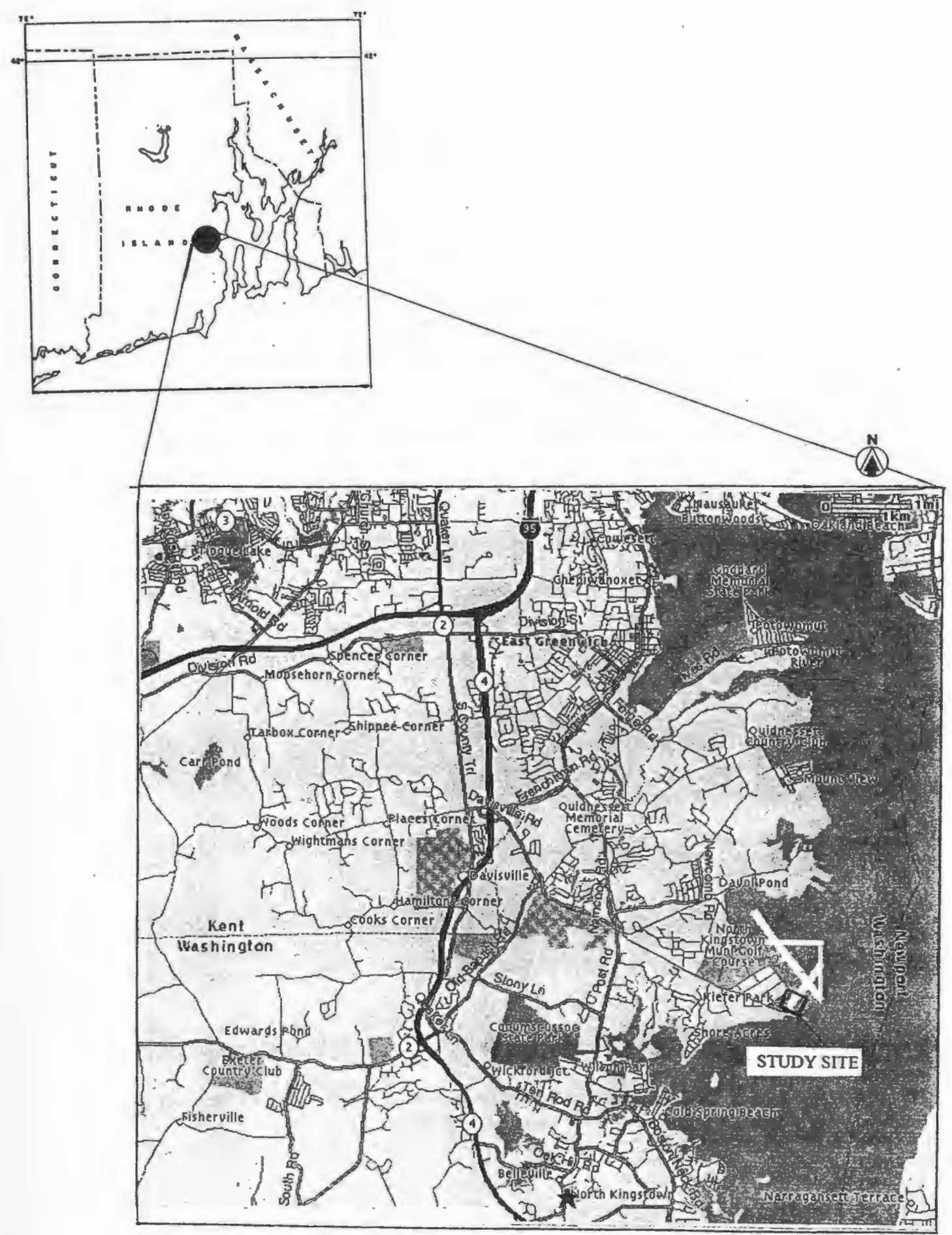

Figure 1.1-Map showing location of study area, the former Davisville-Quonset

Point Naval Complex in North Kingstown,R.I

(Adapted from MapQuest.com., 1999) 


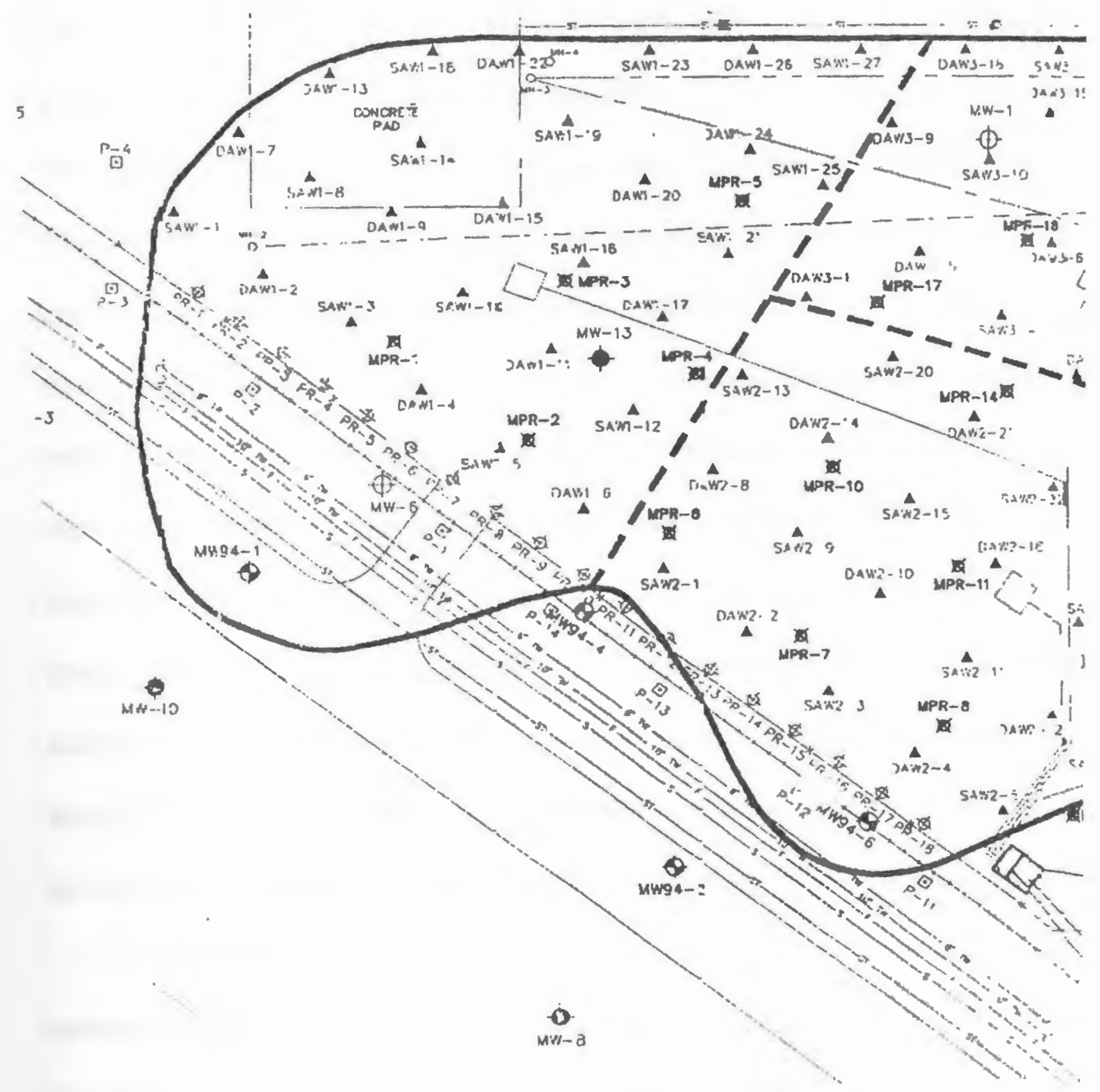

\section{LEGEND}

PR - Product recovery wells

MPR-Manual Product recovery wells

Figure 1.2-Map showing location of the product recovery wells on the contaminated site. 


\subsection{CONVENTIONAL REMEDIAL TECHNIQUES}

The traditional and most popular method of disposal of contaminated soil has been excavation followed by incineration or landfilling. These measures are lengthy and very expensive when considering the removal, transportation, and disposal of soil. The 1984 amendments of the Resource, Conservation, and Recovery Act (RCRA), and the Superfund Amendment and Reauthorization Act (SARA) of 1986 require treatment technologies and remedial measures which permanently and significantly reduce the mobility, toxicity or volume of hazardous waste. Treatment alternatives such as excavation and disposal of hazardous wastes which do not render the wastes inert are discouraged. The major disadvantages of landfilling are that the contaminated soil is not rendered inert, and available land-filling spaces are limited. Incineration of contaminated soil faces similar problems as the ash is considered hazardous and has to be land-filled. Furthermore, excavation can be prohibitive in the presence of underground and above-ground structures, groundwater table and utilities.

Contaminated soils are often contained to prevent the movement of harmful substances going into the groundwater or surrounding soils by erection of slurry formed walls which will either protect the contaminated soil or completely enclose it. This method requires constant monitoring and long term maintenance. 


\subsection{IN-SITU REMEDIAL TECHNOLOGIES}

\subsubsection{Air Stripping}

Air stripping is an established technique for removing volatile organic contamination from soils and groundwater. Air stripping has been effectively used to reduce the concentration of taste - and odor - producing compounds and organics. In air- stripping, toxic chemicals in the liquid phase are transferred to gas phase; and this is done when air is moved through the soil using a series of injection wells, the contaminants volatilize and are displaced from the soil by the injected air. The contaminants are then captured from the soils using extraction pumps and a series of extraction wells.

Henry's coefficient is a good indicator of how effectively an organic compound can be removed by air stripping. The greater the Henry's coefficient of the compound, the less the volume of air required for stripping the compound from water. The rate at which a volatile compound is removed from water through air stripping depends on the air to water ratio, contact time, available area for mass transfer, temperature of the water and air, physical and chemical properties of the chemical (Adams et al, 1991). The removal efficiency or rate can be increased by heating the air to increase the volatilization of the contaminants. The advantages of this method are that it's simple, relatively inexpersive and can be used to a significant depth in the unsaturated zone. 


\subsubsection{Soil Vapor Extraction}

This is a widely used method to remediate subsurface materials contaminated by volatile organic chemicals such as gasoline, jet-fuel and chlorinated solvents.

In this method, soil vapor is drawn to extraction zones through vertical or horizontal well screens where a vacuum is applied. Application of this method is similar to that of air-stripping except that air is pulled through the soil by a vacuum instead of being pushed through . However, this method did not remove low concentration of TPH within a reasonable time when contaminants are a mixtures of volatiles and semi-volatiles, and are located in heterogenous soil media (Choo et al,1997). This method was used for removing $1700 \mathrm{~kg}$ of TPH from hydrocarbons contaminated soil and groundwater by the US. Environmental Protection Agency (USEPA) and US. Coast Guard (USCG) in 1994 at the USCG Support Center in Elizabeth City, North Carolina.

\subsubsection{Soil Washing}

Soil washing is a promising technology that can be utilized in the treatment of petroleum-hydrocarbon-contaminated soils. As defined by Nash et al (1988), soil washing is the mechanical or chemical dispersal of contaminated soil in order to dislodge the contaminants from the soil as much as possible. The washing process fractionates the contaminated soils into different particle-sizes fractions (sands, silts and clays) and removes contaminants from the soil by mechanical shearing, dispersion. emulsification, dissolution, air-stripping, froth flotation or a 
combination of these. After which an appropriate post wash treatment is then applied.

\subsubsection{Electro-Osmosis}

Electro-osmotic technology (EO) has been used since the 1930's for removing hydrocarbons especially from clays, silts and fine sands. Electro-osmosis has been postulated to induce migration of pesticides, or organics out of contaminated soils (Segall et al, 1980). Electrodes are placed in the contaminated soils; and water is continuously replenished at the anodes. The contaminated pore water will be displaced by the fresh water. This replenishment technique has potential for flushing soluble contaminants from fine grained soils that have low hydraulic conductivities. Fine grained soils, once contaminated. become a persistent source of leachable hazardous chemicals. Innovative technologies are needed for the decontamination of these tight soils.

For fine soils with low hydraulic conductivities, electro-osmosis can induce flows that would normally require extraordinary or infeasible hydraulic gradients. Fine grained soils such as clays or silts posses an electrical double layer of negative and positive ions at the solid-liquid interface (Segall et al, 1990). The stationary soil particles are negatively charged while the positively charged counter- ions are present in the solution and are mobile. When a direct current (DC) electric field is applied to the moist soil mass, mobile cations migrate to the cathode and the water molecules which hypothetically contain most of the contaminants are dragged along. This way the contaminants are mobilized by EO from within the fine grained soils into the adjacent coarse-grained soils (in-situ) where they could be biologically treated. 


\subsubsection{Vitrification}

In-situ vitrification is a method in which the contaminated soil is electrically melted at high temperature and transformed into a chemically inert and stable form of glass. Electrodes placed into the ground are used to heat the soil to a high temperature of about $3600^{\circ} \mathrm{F}$ which pyrolizes the organics and drives the off-gases to the surface to be contained. The inorganics are trapped within the vitrified glass and thereby rendered immobile. This process is applicable to a wide range of contaminants, including metals and radioactive waste. Because of it's high cost, it's use is restricted to the more troublesome contaminants such as radioactive waste and PCB's.

\subsubsection{Solvent Extraction}

This is a method of removing contaminants from a solid phase by contacting with a non - aqueous fluid that dissolves and mobilizes the contaminants. The fluid is then separated from the solids and reclaimed, thus greatly reducing the concentration of the contaminants in soils.

The commonly used fluids are organic solvents, liquefied gases or supercritical fluids that have affinity for the contaminants in concern. This process involves solubilization of contaminants from the particle pore space, diffusion of contaminants from the solid and washing the extract from the surface of the solids. Hall et al (1990) have demonstrated that solvent extraction is an effective method for reducing contaminants below the action levels for sediments and soils contaminated with PCB's, oil refinery wastes and pesticides. However, contaminated soils with high moisture content have to be de-watered before solvent extraction can be applied on them. 


\subsubsection{Supercritical Fluid Extraction (SFE)}

The potential environmental threat of the large amount of PCB's lead to the development of effective PCB's cleaning techniques. Among these efforts, the use of supercritical fluid extraction for removal of toxic organics from contaminated soils is receiving much attention. This use of SFE in analytical chemistry to replace conventional liquid extraction have been widely reported (Gonasgi et al, 1991). This is a method in which supercritical fluids with unique properties such as low viscosity, high diffusivity are made to come in contact with the contaminated soils at high pressure and moderate temperature. Small changes in pressure or temperature of the system can cause large changes in the density of the solvent and therefore its ability to solubilize heavy molecular weight and non - volatile waste compounds from the soils. Gonasgi et al (1991) reported the success of removing benzene, phenol, $\mathrm{p}$-chlorophenol and $\mathrm{m}$-cresol from aqueous streams by using $\mathrm{SC}-\mathrm{CO}_{2}$. Following extraction, the waste compound can be completely precipitated from the solvent by means of a drop in pressure to below the solvent's critical conditions. The supercritical fluid's high diffusivity makes its extraction technique more efficient than those of liquid solvents.

\subsubsection{Bioremediation}

This is a dynamic method that is used to remove petroleum products such as gasoline, diesel and jet-fuel from the soils and groundwater. Bioremediation as a method is used for removing petroleum hydrocarbons from soil and groundwater by enhancing biodegradation with the addition of either oxygen or nutrients, or both to the 
contaminated bodies ( Choo et al, 1997).

In biodegradation, micro-organisms use the petroleum hydrocarbons as an energy source, producing carbon-dioxide and water as the end products. Biodegradation occurs either in the presence of dissolved oxygen (aerobic) or without dissolved oxygen(anaerobic). For petroleum hydrocarbons, aerobic biodegradation can occur at faster rates than that of anaerobic biodegradation. With aerobic degradation, oxygen is used along with nutrients such as phosphate and nitrates by the micro-organisms to metabolize the hydrocarbons, while under anaerobic biodegradation, only compounds such as ferric ion, sulfate and nitrate are used, without oxygen. Addition of oxygen, nutrients or both to the contaminated systems stimulate the endemic microbial population resulting in increased bio-mass and enhanced biodegradation.

\subsubsection{Carbon Adsorption}

Carbon adsorption has been widely used for removing contaminants from water and have been designated a baseline technology for removal of organic contaminants from water. Activated carbon has been widely used for drinking water in United States to control taste and odor. Adams et al (1991) stated that granular activated carbon (GAC) has proven through many bench / plant / field scale studies to be an effective treatment process for removing a broad spectrum of organics from water.

Randtke et al (1983) wrote that granular activated carbon was an excellent adsorbent for many of the organic contaminants present in water and wastewater discharges. Its use is often preferred when a significant reduction of organic pollutants, especially those that are non-biodegradable is required. Activated carbon adsorption is based 
on the ability of specially prepared carbon to remove a wide range of organics from liquid solution by adsorption. The carbon can either be powdered activated carbon (PAC) or granular activated carbon(GAC). The adsorptive properties of the PAC and GAC are similar. since they depend on pore size and the internal surface area of the pore for adsorption. Besides the adsorptive capacity of activated carbon, it also has the ability to withstand thermal reactivation and resistance to attrition losses during transport and handling. The practical application of activated carbon in water and wastewater depend on the reuse of most of the carbon. During use, the carbon gradually becomes saturated with the solute being adsorbed so it eventually losses its capacity to adsorb more contaminants. The ability to be reactivated makes the use of activated carbon economically viable.

(i) Carbon selection

There are many commercially available types of activated carbon, each properties that make it more suitable for use in certain applications than others. The initial consideration in the design of any activated carbon system is carbon selection. The selection of any activated carbon will depend on it's ability to remove the contaminants of concern and meet other system requirements such as pressure drop (head loss), carbon transport, and reactivation. The type of carbon that is most suited for a given application is often determined experimentally by creating an adsorption isotherm. An isotherm study is a laboratory simulation of a batch process in which 
activated carbon is contacted with a known concentration of the contaminants of concern under continuous mixing until the adsorption reaches equilibrium. The isotherm result will give the measurement required to obtain the Freundlich isotherms. The Freundlich isotherm is commonly used to determine the carbon adsorptive capacity under the optimal condition.

(ii) Adsorber Configuration

In practice, single or multiple adsorbers that are arranged and operated in various configurations to obtain the most efficient use of the activated carbon may be used. The two basic modes of operation for GAC adsorbers are fixed bed and moving bed. In a fixed bed, the carbon in the adsorber remains stationary and the flow can be downwards or upwards. In the moving bed adsorber, the carbon expands slightly with an upward flow. Adsorbers can be combined in series or parallel operation depending on the application requirements. Operating columns in series allows complete exhaustion of the first column without releasing significant amount of contaminants in the effluent and removal of the first column for regeneration without distrupting the treatment process,(Clark et al, 1989). Parallel adsorber minimizes head loss and requires large total flow-rate. Downward flow enables carbon adsorption to serve as a suspended solids filter as well as an adsorber, though will require back-washing to dislodge and remove suspended solids accumulated on the surface of the bed. Up-flow adsorbers are preferable for use for high suspended solids concentration because it does not require back-washing. 
(iii) Effects Of Empty Bed Contact Time

Empty Bed Contact time (EBCT) is one of several factors that determine the length of GAC operation before replacement or reactivation. Therefore, in designing an new system, the best EBCT relative to performance criteria and cost is chosen. Longer EBCTs provided more efficient use of GAC, however, beyond a certain EBCT, no apparent advantage will be gained by additional contact time (Clark et al, 1989)

(iv) Design of activated carbon system

The important variables in the design of an activated carbon system are the contact time, breakthrough characteristics, flow-rate and carbon use. Carbon use determines the amount of carbon that needs to be replaced. Empty bed contact time (EBCT) is the carbon bed volume divided by the flow-rate $(\mathrm{Q})$ of the liquid through the adsorber. Adsorber volume depends on bed volume and how much freeboard or excess vessel capacity is required. Freeboard may range up to about $50 \%$ for fixed bed and expanded bed systems, upflow pulsed bed requires virtually no freeboard. Contact time can be varied by changing flow-rate at constant bed depth or changing bed depth at constant flow-rate.

Breakthrough point is defined as the point where the solute concentration in the effluent exceeds the treatment objective. Shorter contact time results in earlier breakthrough. Longer contact time delays breakthrough and improves carbon utilization. The percentage of total carbon that is exhausted at breakthrough in a deeper bed is greater than that of a shallower bed. However, beyond a certain point, additional adsorber volume merely acts as storage capacity for spent carbon. 
additional adsorber volume merely acts as storage capacity for spent carbon.

Therefore, there is an optimum carbon bed depth for the influent understudy from the perspective of adsorber cost alone. The contact time that will be selected for design will be one which yields the most reasonable adsorber volume and reactivation frequency ( Clark et al,1989). There is clearly an economic tradeoff between frequency and adsorber volume. Breakthrough depends on the characteristics of both the influent stream and the carbon bed. Different solutes with different carbon will yield different slopes for breakthrough curves at a given contact time.

Figure 1.3 shows the sequence of carbon exhaustion in a carbon column. Initially, the effluent from the column has a very low concentration of solute. Most of the solute has been adsorbed by the upper zone of the carbon column.

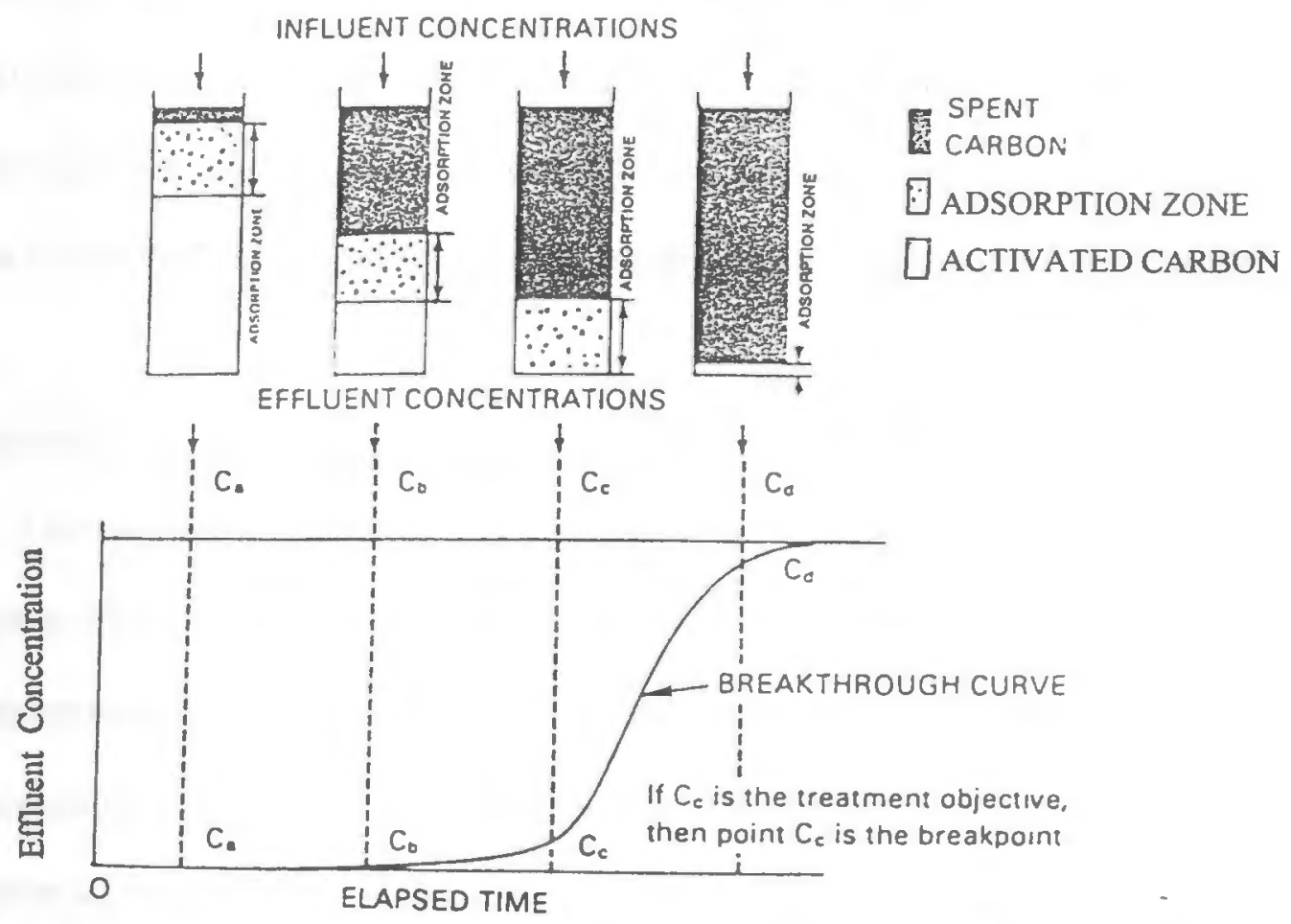

Figure 1.3-Carbon adsorption breakthrough curve showing movement of adsorption zone. (Adapted from Clark et al, 1989) 
This zone within the carbon bed where the adsorption takes place is referred to as "adsorption zone or mass transfer zone"(MTZ). As more liquid flows through the bed, the adsorption capacity of the upper section of carbon gets exhausted and the adsorption zone moves downward with a gradual increase in the effluent solute concentration. Finally, as the whole bed nears exhaustion, the effluent solute concentration increases rapidly approaching the influent concentration.

Breakthrough curves are very important to the design of an activated carbon column because they define the relationship between the physical-chemical parameters of the solvent-solute-carbon system including the flow-rate, bed size, carbon usage, configuration of columns and the treatment objective. In the design of a granular activated carbon adsorption system, the treatment objective defines the performance needs of the system while the influent characteristics affect the choice of system size and configuration. For a given treatment objective, analysis of several breakthrough curves for the influent of concern provides the information required to size the adsorber.

(v) Column Design Using Scale-Up Approach

This method was developed by Fornwalt et al (1966) for the design of carbon adsorption columns. The advantages of this method are its simplicity and the relatively few experimental data required. The disadvantage of this method is that it does not take into account the effect of unit hydraulic flowrate. This design procedure does not require adsorption to be represented by an isotherm. The principal experimental information required is a breakthrough curve from a laboratory or pilot scale column, that has been 
operated at the same liquid flowrate in terms of bed volumes per time, $\mathrm{Q}_{\mathrm{b}}$ as the full scale column, as well as the contact time where the contact time, $T$ is equal to $\in / \mathrm{Q}_{b}$, and $\epsilon$ is the pore fraction. Since the contact times are the same, it is assumed that the volume of liquid treated per unit mass of adsorbent, $\mathrm{V}_{\mathrm{b}}$ for a given breakthrough in the laboratory column is the same as the field scale column. Before the breakthrough test, selection of a satisfactory liquid flowrate, $\mathrm{Q}_{b}$ in bed volume per unit time is important. This may be estimated from calculation using such information as the required tbreakthrough volume, solute concentration, the maximum solid-phase concentration and other pertinent data. Usually, $\mathrm{Q}_{\mathrm{b}}$ is from 0.2 to 3.0 bed volume per hour.

The bed volume of the full scale column is given by

$$
(B V)=Q / Q_{b}
$$

Where $\mathrm{Q}$ is the design liquid flowrate. The mass or weight of the adsorbent, $\mathrm{M}$, for the design column is

$$
M=(B V)\left(\rho_{s}\right)
$$

where $\rho_{\mathrm{s}}$ is the adsorbent bulk density. From the breakthrough curve for the laboratory/pilot scale column, the breakthrough volume, $\mathrm{V}_{\mathrm{b}}$, is determined for the allowable effluent solute concentration, $\mathrm{Ce}$. The volume of liquid treated per unit mass of adsorbent, $\overline{\mathrm{V}}_{\mathrm{B}}$ is determined by

$$
\mathrm{V}_{\mathrm{B}}=\mathrm{V}_{\mathrm{B}} / \mathrm{M} \text {, }
$$

where $\mathbf{M}$ is the mass of the adsorbent in the laboratory column. The mass of the adsorbent exhausted per hour,

$$
\mathrm{M}_{\mathrm{t}}=\mathrm{Q} / \mathrm{V}_{\mathrm{B}} \text {. }
$$

The breakthrough time, $\mathrm{T}$, is 


$$
\mathrm{T}=\mathrm{M} / \mathrm{M}_{\mathrm{t}}
$$

Where $\mathrm{M}$ is the mass of the adsorbent in the field scale column. The calculated breakthrough volume, $\mathrm{V}_{\mathrm{B}}$, for the allowable breakthrough concentration, $\mathrm{Ce}$, for the Field scale column is

$$
\mathrm{V}_{\mathrm{B}}=\mathrm{QT}
$$

If calculated breakthrough time, $\mathrm{T}$, or the calculated breakthrough volume is not acceptable, another liquid flowrate, $\mathrm{Q}_{b}$, to give the required time or volume should be determined from available breakthrough data. The laboratory breakthrough should be repeated using the new $\mathrm{Q}_{b}$ value, and repeat calculating all other parameters

\section{(vi) Evaluation of Bed -depth Service Time (BDST)}

Hutchins (1974) presented this simplified way of examining the bed - depth service time (BDST) in GAC system with several columns. Two horizontal lines are drawn through the breakthrough curve of the columns at $\mathrm{C}_{\text {out }} / \mathrm{C}_{\mathrm{in}}=0.1$ and 0.9 in Figure1.4

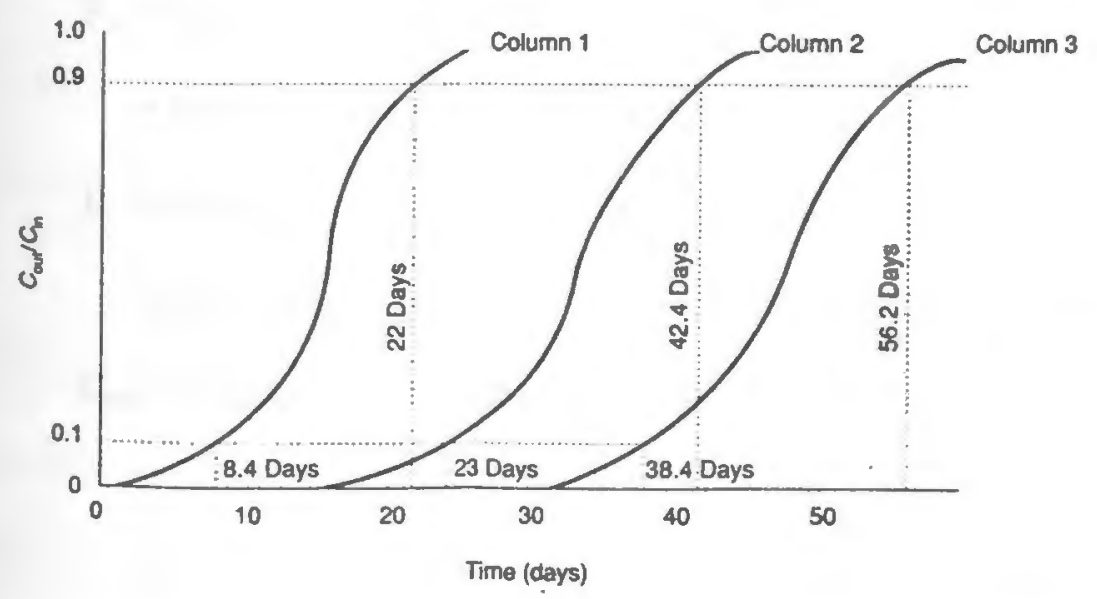

Figure 1.4- Laboratory breakthrough curves for three columns, each 2-inch diameter and $7.5 \mathrm{ft}$ deep . (Adapted from Hutchins, 1974) 
The Bed-depth service time curve is plotted in Figure 1.5 with the lower line representing $90 \%$ removal of organics. This line can be presented by the Bohart-Adams equation. $t=a X+b$

where $\mathrm{X}=$ depth in column (m)

$$
\mathrm{a}=\mathrm{F}_{1} \mathrm{~N} / \mathrm{C}_{\mathrm{in}} \mathrm{V} \text {, }
$$

where : $\mathrm{a}=$ slope $(\mathrm{hr} / \mathrm{m})$

$\mathrm{F}=$ Conversion factor for units $=10^{3}$ for metric units, 1998 if $\mathrm{N}$ has units of $\mathrm{Ib} / \mathrm{ft}^{3}$ and $\mathrm{V}$ has units of $(\mathrm{gal} / \mathrm{min}) / \mathrm{ft}^{2}$

$\mathrm{N}=$ adsorptive capacity of carbon (mass of contaminant removed per volume of carbon in the column)

$\mathrm{C}_{\text {in }}=$ influent capacity

$\mathrm{V}=$ superficial velocity through column $(\mathrm{m} / \mathrm{hr})\left(\mathrm{m}^{3} / \mathrm{hr}\right.$ per $\mathrm{m}^{2}$ of column)

$\mathrm{b}=\left(\mathrm{F}_{2} / \mathrm{KC}_{\text {in }}\right) \times \operatorname{In}\left\{\left(\mathrm{C}_{\text {in }} / \mathrm{C}_{\text {out }}\right)-1\right\}$,

where: $\mathrm{b}=$ intercept $(\mathrm{hr})$

$F_{2}=$ conversion factor $=10^{3}$ for metric units

$=16,025$ if $\mathrm{K}$ has units of $\mathrm{ft}^{3} / \mathrm{Ib}-\mathrm{hr}$

$\mathrm{K}=$ adsorption rate constant required to move an adsorption through the critical depth $\left(\mathrm{m}^{3} / \mathrm{kg}-\mathrm{hr}\right)\left(\mathrm{m}^{3}\right.$ of liquid treated per $\mathrm{kg}$ impurity fed per $\mathrm{hr}$ )

$\mathrm{C}_{\text {out }}=$ contaminant concentration at breakthrough $(\mathrm{mg} / \mathrm{L})$ 


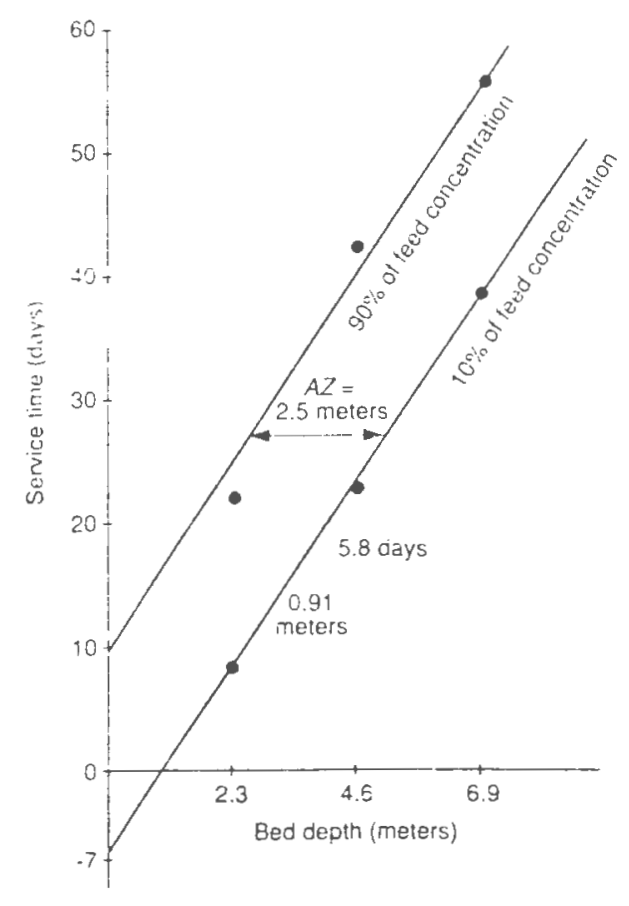

Figure 1.5-Bed-Depth Service Time curves.(Adapted from Formwalt et al.1966)

This technique provides carbon dosage based on a single fixed bed. The actual carbon usage rate will be lower for beds in series. At $t=0$

$$
\mathrm{X}(0)=\left(\mathrm{F}_{2} / \mathrm{F}_{1}\right) \times(\mathrm{V} / \mathrm{NK}) \times \operatorname{In}\left\{\left(\mathrm{C}_{\text {in }} / \mathrm{C}_{\text {out }}\right)-1\right\}
$$

$\mathrm{X}(0)$ or the abscissa intercept is the critical bed depth (i.e, the minimum to obtain satisfactory effluent at time zero). The ordinate intercept, $b$, measures the time required for an adsorption zone to pass through the critical depth. The slope term, a, provides a measure of the velocity of the adsorption zone (i.e, the speed at which carbon is exhausted). The velocity of the adsorption zone is $1 / \mathrm{a}$. 
The rate of carbon utilization may be determined by using this velocity:

Carbon utilization $=$ area $\times(1 / a) \times$ unit weight

Equation 1.7 can be modified after the BDST curve has been established to account for changes in flow rate: $t=a^{\prime} X+b$

$$
a^{\prime}=a\left(V / V^{\prime}\right)
$$

where $V^{\prime}=$ the new flow rate $\left(\mathrm{m}^{3} / \mathrm{hr}\right.$ per $\mathrm{m}^{2}$ of column)

Similarly, the BDST equation is easily modified for changes in the feed concentration

$$
\begin{aligned}
& a^{\prime}=a \times C_{\text {in }} / C_{\text {in }}^{\prime} \\
& b^{\prime}=b \times \frac{C_{\text {in }}}{C_{\text {in }}^{\prime}} \times \frac{\ln \left\{\left(C_{\text {in }}^{\prime} / C_{\text {out }}^{\prime}\right)-1\right\}}{\ln \left\{\left(C_{\text {in }} / C_{\text {out }}\right)-1\right\}}
\end{aligned}
$$

where $C_{\text {in and }}^{\prime} C_{\text {out }}^{\prime}$ represent the influent and effluent concentration under the new operating conditions.

The "Mass Transfer Zone" is the horizontal distance between the curve the $10 \%$ and $90 \%$ exhaustion. Where a number of columns in series are used, the total number of columns is related to the height of the adsorption zone by:

$$
\mathrm{n}=(\mathrm{AZ} / \mathrm{d})+1
$$

where $\mathrm{n}=$ number of columns in series

$$
\begin{aligned}
& A Z=\text { height of adsorption zone } \\
& d=\text { height of a single column }
\end{aligned}
$$




\subsection{EXPERIMENTAL PROCEDURES \& ANALYTICAL METHODOLOGY}

\subsection{Introduction}

This study is specifically targeted to evaluate remediation techniques for a jet fuel contaminated site in the former Davisville-Quonset point Naval Complex, North Kingstown, RI. Groundwater samples were obtained from different product recovery wells on the site using bailers. Samples obtained from these recovery wells were mixed together and stored with minimal headspace at room temperature.

The analysis procedures consisted of the following :

- The extraction and analysis by gas chromatography (GC) of the contaminated water to determine concentrations of the Total Petroleum Hydrocarbons $(\mathrm{TPH})$ in the water.

- The extraction, analysis and dilution of highly concentrated samples to concentrations similar to that of the true representative of the contaminated ground water.

- Batch adsorption isothermal studies of aged jet fuel/granular activated carbon samples to obtain the Freundlich isotherm parameters.

- The construction of granular activated carbon columns.

- The extraction and analysis of TPH in the influents and effluents from the sampling ports of the activated carbon columns to obtain the breakthrough curves. Analysis of the breakthrough curves to assess the design of the adsorber volume. 


\subsection{Gas Chromatograph Conditions}

The gas chromatograph used for the experiments was Shimadzu 14A series equipped with a Shimadzu CR501 Chromatopac integrator, a Shimadzu AOC - 17 auto injector, a flame ionization detector (FID), and a JW $30 \mathrm{~m} \times 0.45 \mathrm{~mm}$ I.D DB - TPH capillary column. Optimum analytical results were achieved using an oven temperature program holding the initial temperature of $40^{\circ} \mathrm{C}$ for 2 minutes then increasing to $250^{\circ} \mathrm{C}$ at $15^{\circ} \mathrm{C} / \mathrm{min}$. The detector temperature was maintained at $270^{\circ} \mathrm{C}$. A $2 \mathrm{ml} / \mathrm{min}$ helium flow was used for carrier gas.

Because of the changes that might have taken place within the constituents of the groundwater contaminant due to aging, volatilization, exposure, and interaction with the soils minerals and the groundwater; the contaminants are characterized as Total Petroleum Hydrocarbons(TPH) using EPA method 8015 on analysis of organics using GC/FID.

\subsection{Sampling}

The TPH contaminated water samples were collected with the aid of 1.25 - inch inside diameter PVC bailers from different recovery wells at varying levels below the surface level of the contaminated water in the well. The recovery wells were installed by Drilex Inc, Providence, R.I. and are 3 inches in inside diameter and between 12 and 15 feet deep. Samples collected from the wells were immediately placed in High Density Polyethylene (HDPE) containers. The samples from the different wells were mixed together and stored with minimal headspace at a room temperature. 


\subsection{Calibration standards}

Some of the product recovery wells from which the samples were taken were equipped with filters to separate the contaminants from the groundwater. These contaminants are floating materials that have very little water content in them. In this study, these recovered contaminants are referred to as "free product". The free product of the sample obtained from the site was "dried" using anhydrous sodium sulfate, then placed into a teflon sealed screw cap bottle, stored with minimal headspace in a refrigerator at a temperature of $2^{\circ} \mathrm{C}$ and used as calibrating standards.

\subsection{Methodology For Calibrating Standards}

A $2 \mathrm{~mL}$ vial was weighed, one milliliter of free product was then placed in the vial and re - weighed. The density of the free product was determined using

$$
\rho=M / V \text {, }
$$

where: $\quad \rho$ is the density of free product.

$\mathrm{M}$ is the mass of free product.

$\mathrm{V}$ is the volume of free product.

With the density of free product known, usually $3 \mathrm{~mL}$ of carbon disulfide was placed in a $4 \mathrm{~mL}$ vial, and $40 \mathrm{uL}$ of free product was added into the solvent and mixed thoroughly. The concentration in $\mathrm{mg} / \mathrm{mL}$ of TPH in the solvent was calculated. Dilutions were then made as required. 
A minimum of five different concentrations were always used to obtain a calibration curve. One of them was at a concentration near the detection limit and the other concentrations were made to correspond to the expected range of concentrations found in the samples. All the standards were placed in the vials at zero headspace.

The different standards used were analyzed on the same GC using the same analytical conditions indicated above. A minimum of six different prominent chromatogram peaks were picked as representatives for each concentration.

A response factor for each standard was obtained using

$$
\mathrm{RF}=\mathrm{C} / \mathrm{A}_{\mathrm{s}} \text {, }
$$

Where: $\quad$ is the calculated concentration $(\mathrm{mg} / \mathrm{mL})$

$A_{s}$ is the sum of the area absorbance of the selected peaks.

The concentration $(\mathrm{mg} / \mathrm{mL})$ of a sample (TPH) in the solvent was determined using Where:

$$
\text { Concentration in solvent }=\left(A_{s}\right)(\overline{R F})
$$

$$
A_{s}=\text { Total areas of the peaks similar to calibration standards peaks }
$$

$$
\overline{(\mathrm{RF})}=\text { Mean response factor from the calibration standards }
$$

The concentration $(\mathrm{mg} / \mathrm{L})$ of a sample (TPH) in water was determined by the following calculation.

$$
\text { Concentration in water }=\underbrace{\left(\mathrm{A}_{\mathrm{s}}\right)(\overline{\mathrm{RF}})\left(\mathrm{V}_{\mathrm{T}}\right)}_{\mathrm{V}} \times 1000 \text {, }
$$

Where: $V_{T}=$ Volume of the concentrated extract $(\mathrm{mL})$.

$$
\mathrm{V}=\text { Volume of Contaminated water extracted in } \mathrm{mL} \text {. }
$$

Extracted samples were analyzed the same day they were extracted. 


\subsection{Extraction of Sample}

Carbon disulfide $(5 \mathrm{~mL})$ was added to $250 \mathrm{~mL}$ of sample, shaken for 2 minutes, then was allowed to settle, the TPH dissolved in carbon disulfide settled below the water layer. The TPH in carbon disulfide was gently removed from the water layer using a separatory funnel. The carbon disulfide was dried by passing it through a pasteur pipet containing anhydrous sodium sulfate. The carbon disulfide solution was then stored in a vial at zero headspace at $2^{\circ} \mathrm{C}$. The method of extraction used for this experiment was tested and proven to achieve a recovery rate of over $70 \%$ of the contaminant in the groundwater.

\subsection{Isotherm studies}

An isotherm study is a laboratory experiment in which carbon is contacted with a known concentration of solute under continuous stirring and constant temperature until the adsorption reaches equilibrum. The resulting isotherm is the relationship between the amount of substance adsorbed and it's concentration in the surrounding solution.

Prior to it's use, calgon's Filtrasorb 400 was dried at $130^{\circ} \mathrm{F}$ for 6 hours and kept in an air tight container until it was ready for use. Five different $160 \mathrm{~mL}$ glass bottles were prepared, each containing $10 \mathrm{~g}$ of F- 400, Calgon granular activated carbon and $150 \mathrm{~mL}$ of $9.2 \mathrm{mg} / \mathrm{L}, 6.4 \mathrm{mg} / \mathrm{L}, 5.0 \mathrm{mg} / \mathrm{L}, 3.5 \mathrm{mg} / \mathrm{L}, 1.4 \mathrm{mg} / \mathrm{L}$ TPH contaminated samples. These were equilibrated for 14 days with constant mixing. Next, samples in each beaker were extracted using carbon disulfide and analyzed on the GC to obtain 
final concentrations.

The residual of the granular activated carbon in the recovered sample for extraction often heightened the surface tension in the sample when mixed with carbon disulfide such that not all carbon sulfide used for extraction was recovered. Some dissolved in water and some stayed on the surface of the water due to surface tension. However, recovery of TPH in carbon disulfide was made as it settled below the water. The sample with carbon disulfide was mixed and allowed to settle several times, with removal of the TPH in carbon disulfide done several times before a reasonable volume of carbon disulfide with TPH was recovered.

The mass of solute per unit mass of carbon $(\mathrm{X} / \mathrm{M})$ in $\mathrm{mg} / \mathrm{g}$ was determined as follows:

$$
\mathrm{X} / \mathrm{M}=(\mathrm{Co}-\mathrm{Ce})(\mathrm{V}) / \mathrm{Mc}
$$

where :

$$
\begin{aligned}
& \mathrm{Co}=\text { initial concentration of sample placed in bottle }(\mathrm{mg} / \mathrm{L}) \\
& \mathrm{Ce}=\text { final concentration of sample in bottle after } 74 \text { hours }(\mathrm{mg} / \mathrm{L}) . \\
& \mathrm{V}=\text { Volume of sample placed in the bottle }(\mathrm{L}) . \\
& \mathrm{Mc}=\text { amount of carbon placed in bottle }(\mathrm{g}) .
\end{aligned}
$$

Plotting the $\mathrm{X} / \mathrm{M}$ against the $\mathrm{Ce}$ gave the parameters of Freundlich isotherm.

$$
\mathrm{X} / \mathrm{M}=\mathrm{KCe}^{1 / \mathrm{n}}
$$

Where: $\quad \mathrm{X}=$ amount of chemical adsorbed by activated carbon (mg)

$$
\mathrm{M}=\text { amount of adsorbent }(\mathrm{g})
$$




$$
\begin{aligned}
& \mathrm{K}=\text { constant related to adsorption capacity } \\
& 1 / \mathrm{n}=\text { constant related to adsorption intensity } \\
& \mathrm{Ce}=\text { equilibrum concentration of chemical }(\mathrm{mg} / \mathrm{L})
\end{aligned}
$$

2.8 Grain Size Analysis of Calgon's Filtrasorb 400

$1284 \mathrm{~g}$ of the GAC Calgon Filtrasorb 400 were mechanically sieved through a series of scrupulously cleaned US - standard sieves. Each sieve fraction was weighed.

Figure 2.1 and Table 2.1 show the grain sizes that make up of Calgon's

Filtrasorb $12 \times 40$ mesh sieve size.

Table 2.1-Shows the distribution of Filtrasorb- 400 grain sizes

\begin{tabular}{|c|c|c|c|c|}
\hline $\begin{array}{c}\text { Sieve size } \\
\text { Number }\end{array}$ & Diameter in & $\begin{array}{c}\text { Weight in gm } \\
\text { of } \\
\text { GAC retained }\end{array}$ & $\begin{array}{c}\text { \% Weight } \\
\text { retained }\end{array}$ & $\begin{array}{l}\text { \% Passing by } \\
\text { weight }\end{array}$ \\
\hline 12 & 1.7 & 2.4 & 0.19 & 99.81 \\
\hline 16 & 1.19 & 772.8 & 60.30 & 39.51 \\
\hline 20 & 0.84 & 279.7 & 21.82 & 17.69 \\
\hline 40 & 0.42 & 212.7 & 16.60 & 1.09 \\
\hline
\end{tabular}

From Figure 2.1, the effective grain size, the uniformity coefficient $\left(\mathrm{C}_{\mathfrak{u}}\right)$ and the coefficient of curvature $\left(\mathrm{C}_{c}\right)$ of Filtrasorb 400 are determined. 
(a) Effective grain size $\left(d_{10}\right)=0.64 \mathrm{~mm}$, this is the size such that $10 \%$ (by weight) of the sample consists of particles having a smaller nominal diameter.

(b) Uniformity coefficient $\left(C_{\mathrm{u}}\right)=\mathrm{d}_{60} / \mathrm{d}_{10}=1.30 / 0.64=2.03$ (Well sorted)

$d_{30}, d_{60}$ are the equivalent sizes for $30 \%$ and $60 \%$ of the sample respectively.

(c) The Coefficient of curvature $\left(C_{c}\right)=\left(d_{30}\right)^{2} / d_{60} x d_{10}$

$$
=(1.05)^{2} /(1.30)(0.64)=1.33
$$

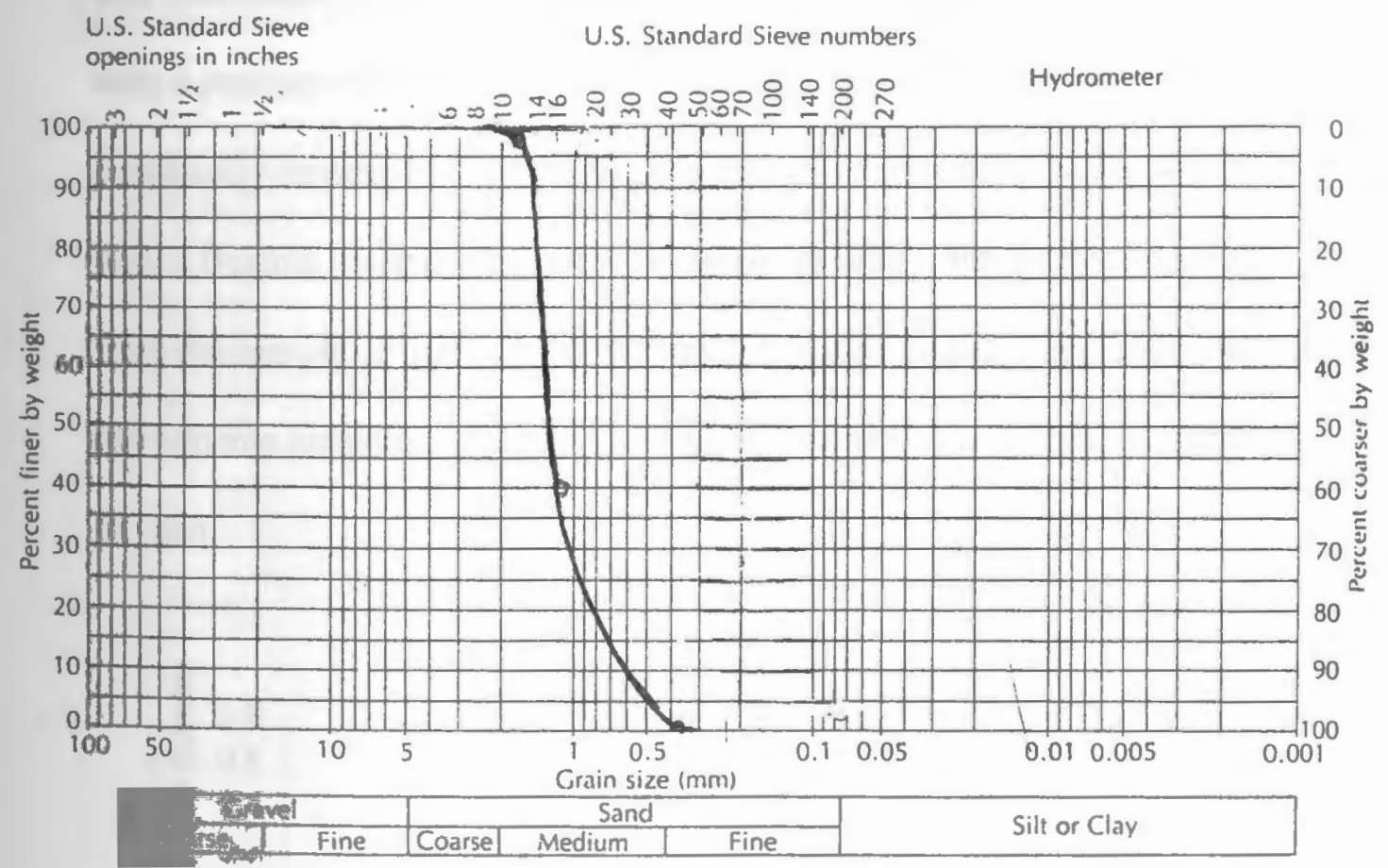

Figure 2.1- graph showing the sieve analysis of Calgon Filtrasorb 400 (F-400) 


\subsection{Design and Operation of GAC Column}

This system consists of $1 / 2$-inch PVC pipes through which sample was pumped into four 3-inch PVC columns configured for an in-series mode of operation. Each column was filled with $735 \mathrm{~g}$ of granular activated carbon, Calgon Filtrasorb 400, mesh size $12 \times 40$. Sampling ports were located between the columns from which influent and effluent samples were taken and analyzed to establish influent and effluent TPH profiles. A KNF variable - speed diaphram pump was used to regulate the flow rate, with a Gilmont flowmeter. The flowmeter was calibrated in the laboratory using different flowrates. Figure 2.2 shows the result of the calibration. A pressure gage was installed to monitor the line pressure in the system. The system was also equipped with a pressure relief valve. The TPH contaminated groundwater was placed and continually replenished and filled to the brim in a seven and half gallons HDPE tank, with a floating piece placed over the sample to reduce the escape of volatile organics from the sample. Figures $2.3 \& 4$ show the system set-up, the gas chromatograph instruments including the tanks that hold the carrier gas, helium, hydrogen and oxygen.

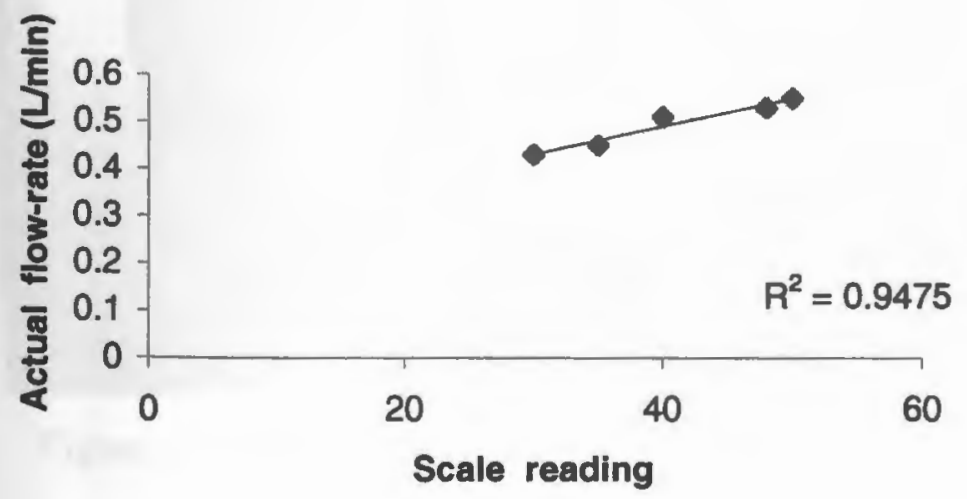

Figure 2.2- Calibration curve for the Gilmont Flowmeter 


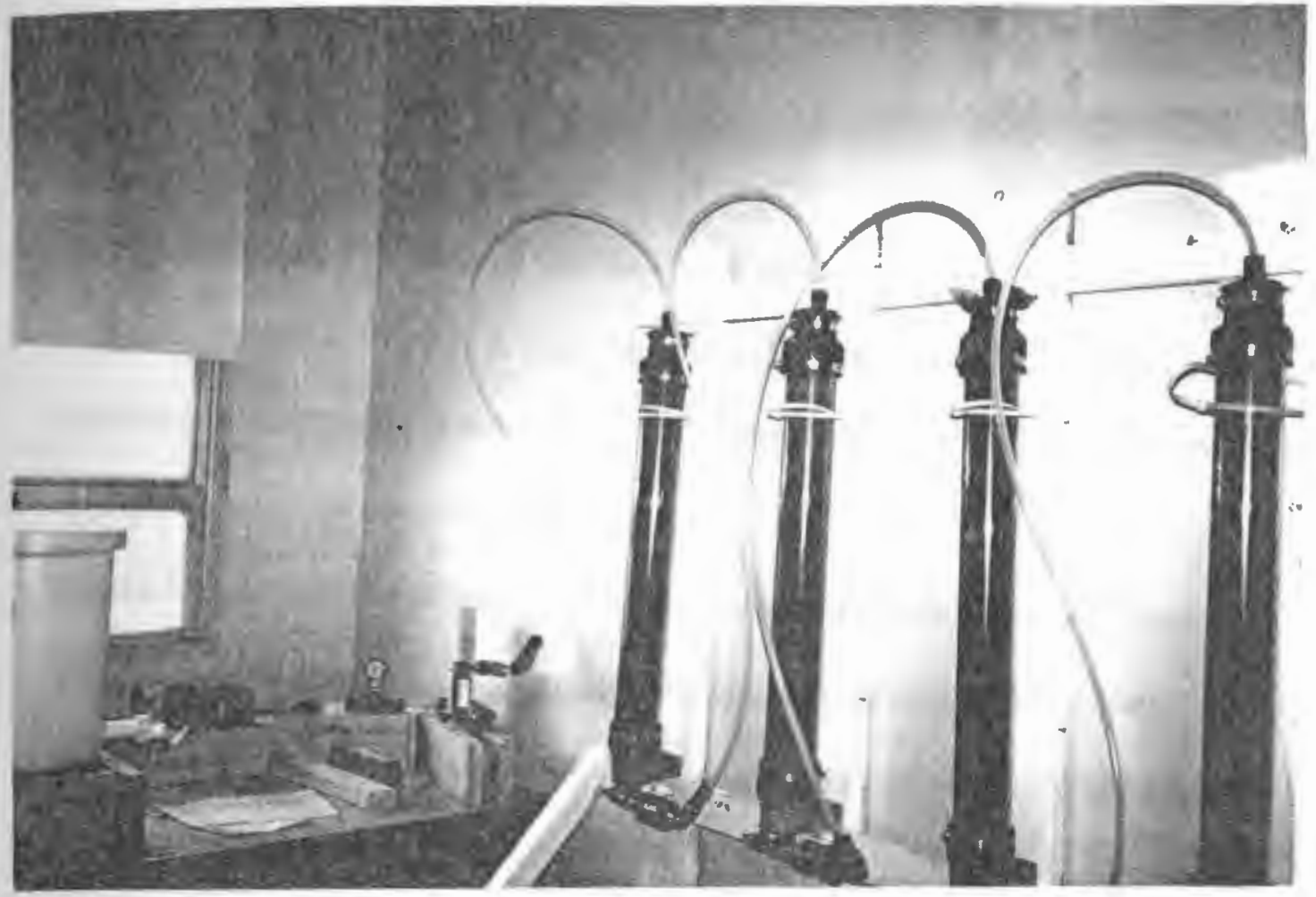

Figure 2.3-Components of Granular Activated Carbon Column System

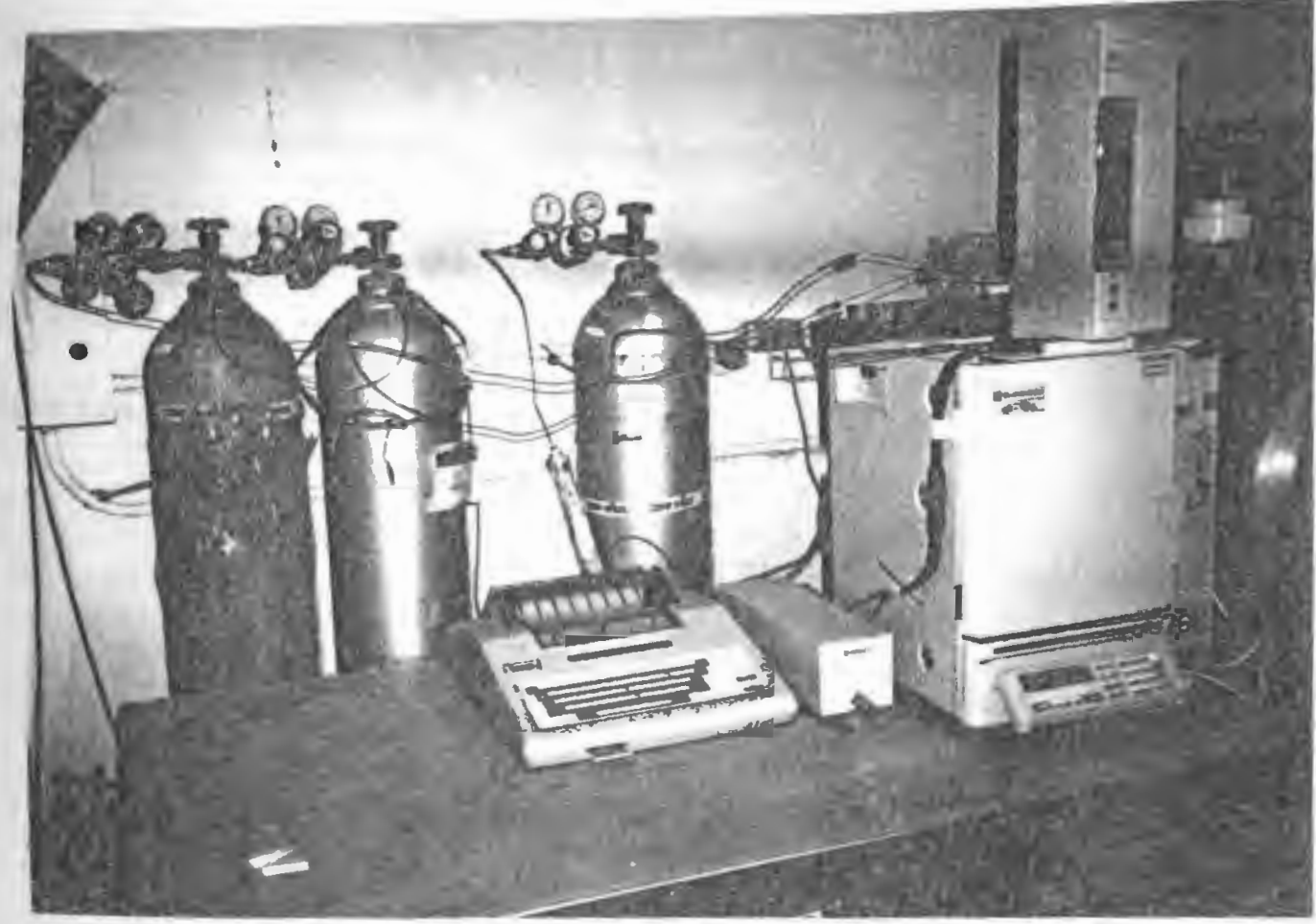

Figure 2.4 - Components for Gas Chromatograph Analysis as used in this experiment 


\subsection{RESULTS AND DISCUSSION}

\subsection{Calibration of TPH Standards}

Quantification of samples were achieved using "free products" as standards as earlier explained in Chapter 2, page 14. The following Figures 3.1-3.12 depict the various chromatograms as obtained in different concentrations of the Total Petroleum Hydrocarbons in carbon disulfide.

Figure 3.1 shows the resolved peaks for the carbon disulfide alone and Figures 3.2, 3.3, 3.4 show $520 \mathrm{ug} / \mathrm{mL}$ commercially available aviation fuel, $400 \mathrm{ug} / \mathrm{mL}$ commercially available JP 5 and $200 \mathrm{ug} / \mathrm{mL}$ of mixture of commercially available aviation fuel and JP 5 respectively, all dissolved in carbon disulfide. Figures 3.5 $3.6,3.7,3.8,3.9,3.10,3.11$ show the chromatograms of $78 \mathrm{ug} / \mathrm{mL}, 186 \mathrm{ug} / \mathrm{mL}$, $284 \mathrm{ug} / \mathrm{mL}, 372 \mathrm{ug} / \mathrm{mL}, 620 \mathrm{ug} / \mathrm{mL}, 1.24 \mathrm{mg} / \mathrm{mL}, 2.4 \mathrm{mg} / \mathrm{mL}$ of aged jet fuel (TPH) respectively. A minimum of six different prominent chromatogram peaks were picked as representatives for each concentration used as standards to construct a standard calibration curve. Figure 3.12 show a standard calibration curve for quantifying the aged fuel contaminated water. 


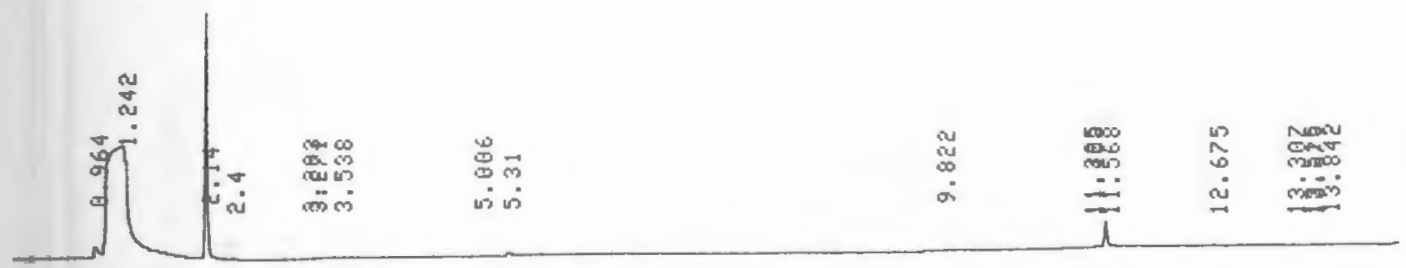

Figure 3.1-chromatograms showing the resolved peaks for carbon disulfide.
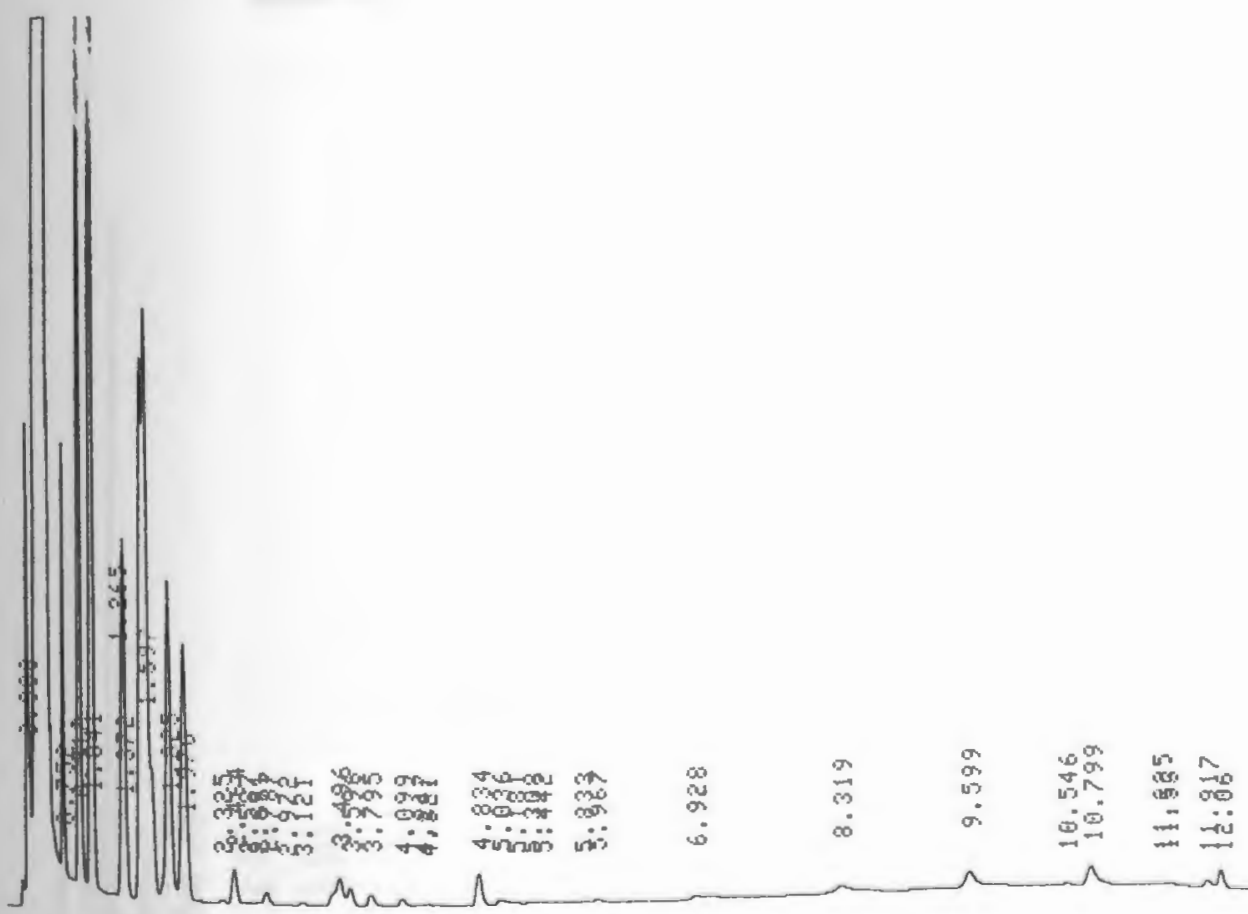

Figure 3.2- Chromatogram for $520 \mathrm{ug} / \mathrm{mL}$ commercially available aviation fuel in carbon disulfide 


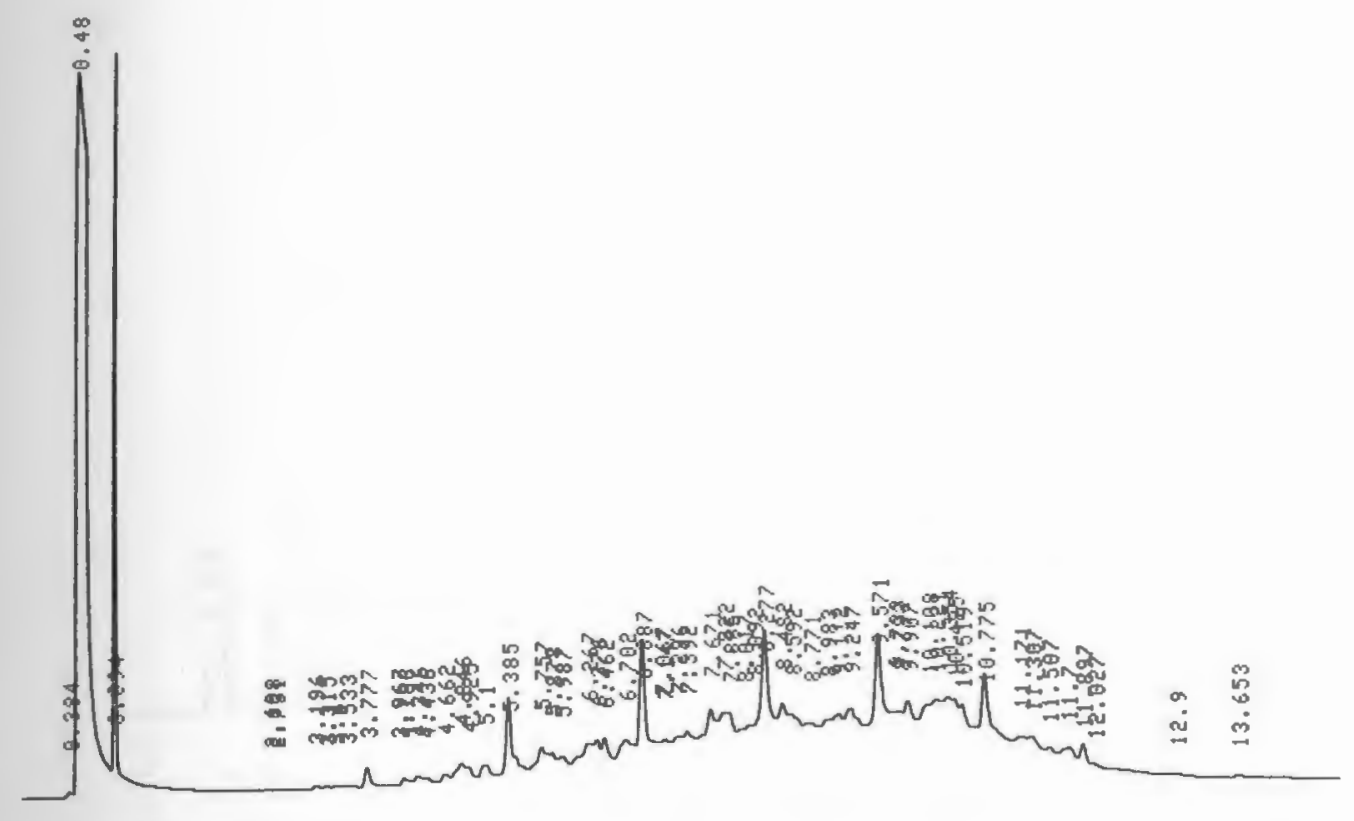

Figure 3.3- Chromatogram for $400 \mathrm{ug} / \mathrm{mL}$ commercially available JP 5 in carbon disulfide

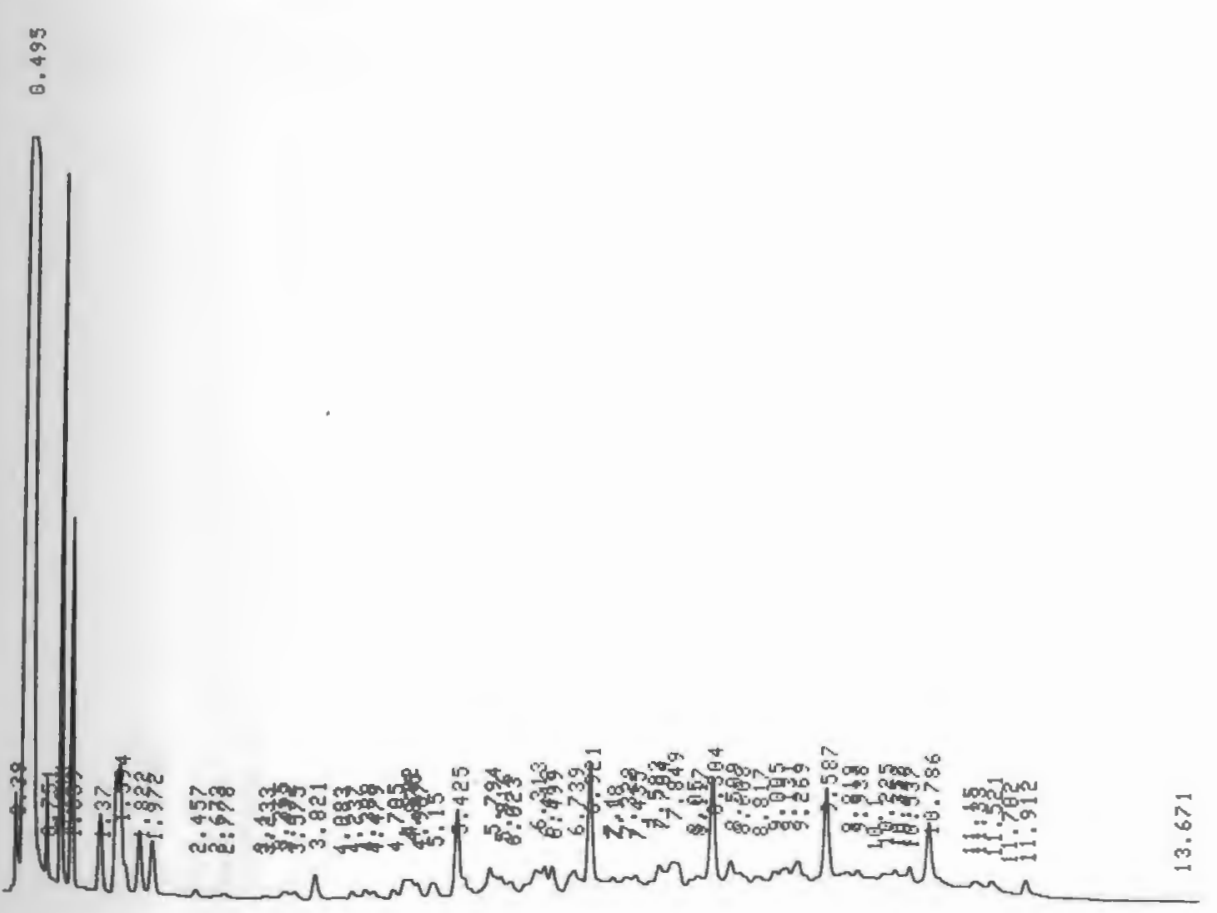

Figure 3.4- Chromatogram for $200 \mathrm{mg} / \mathrm{mL}$ of mixture of commercially available aviation fuel and JP 5 in carbon disulfide 


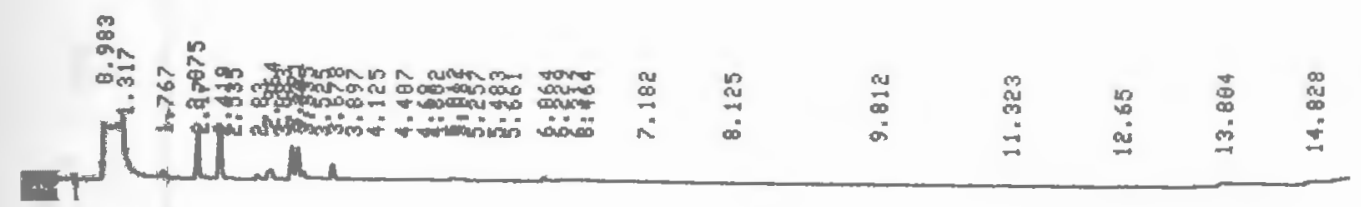

Figure 3.5- Chromatogram for $78 \mathrm{ug} / \mathrm{mL}$ of aged jet fuel (TPH) in carbon disulfide

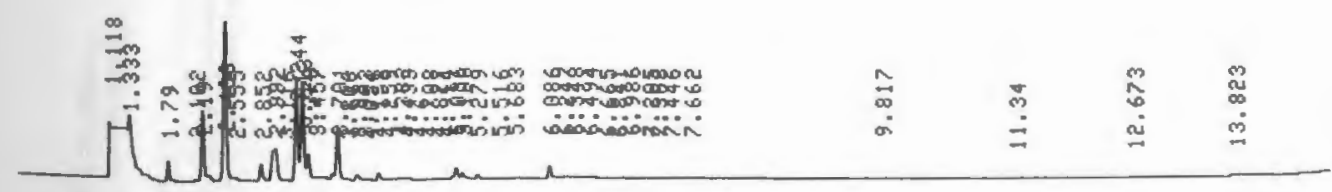

Figure 3.6- Chromatogram for $186 \mathrm{ug} / \mathrm{mL}$ of aged jet fuel (TPH) in carbon disulfide 


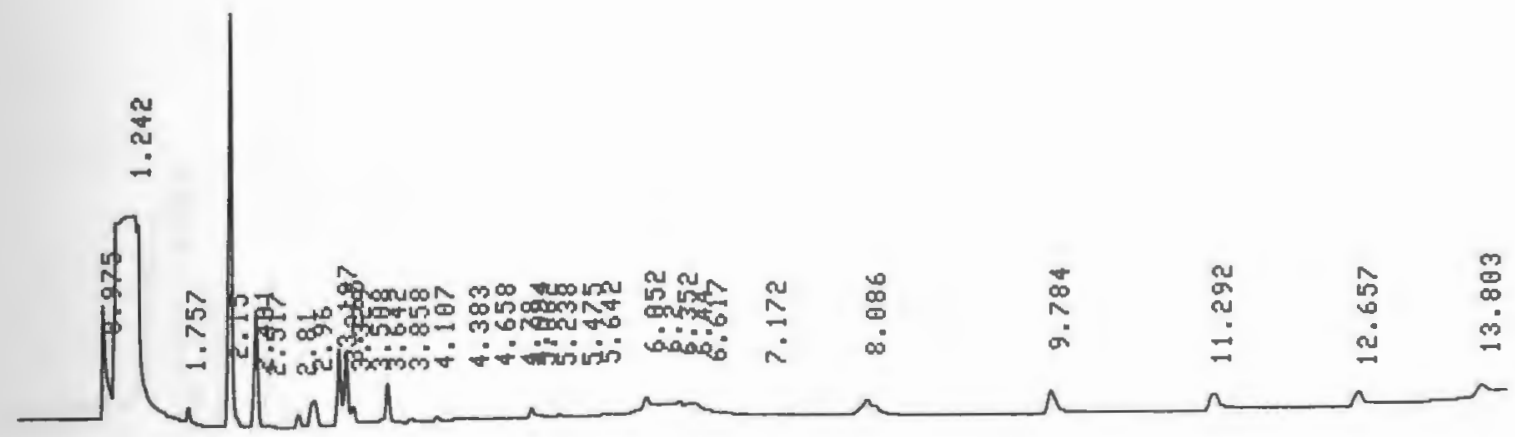

Figure 3.7- Chromatogram for $284 \mathrm{ug} / \mathrm{mL}$ of aged jet fuel (TPH) in carbon disulfide

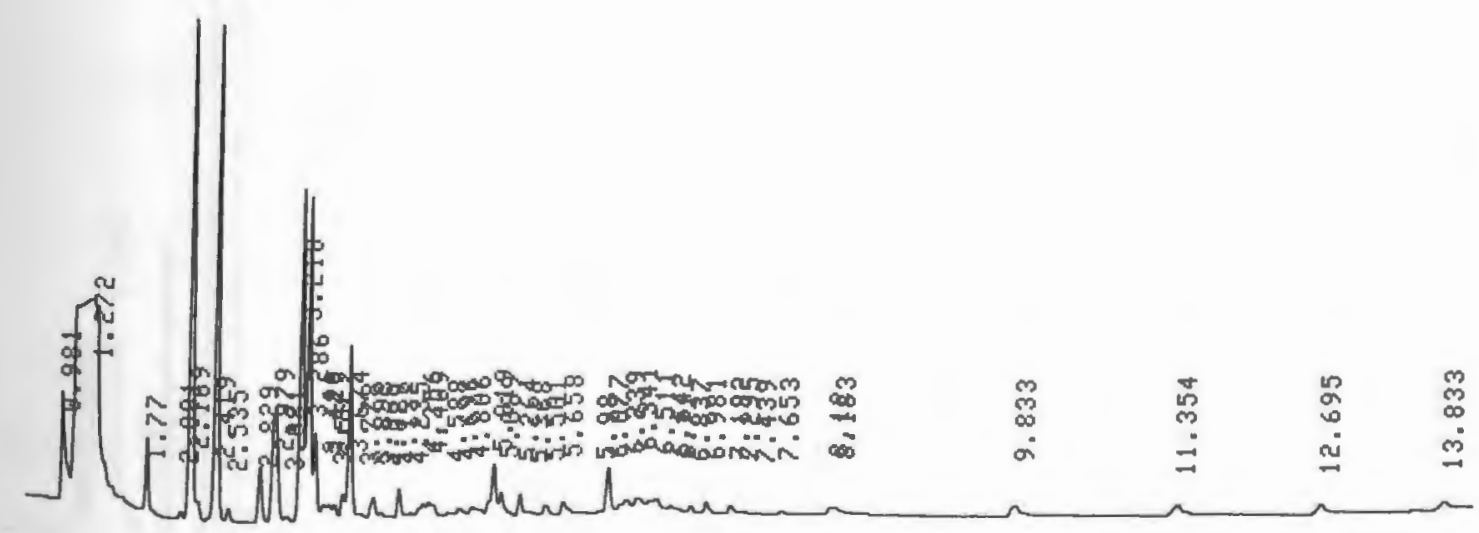

Figure 3.8- Chromatogram for $372 \mathrm{ug} / \mathrm{mL}$ of aged jet fuel (TPH) in carbon disulfide 


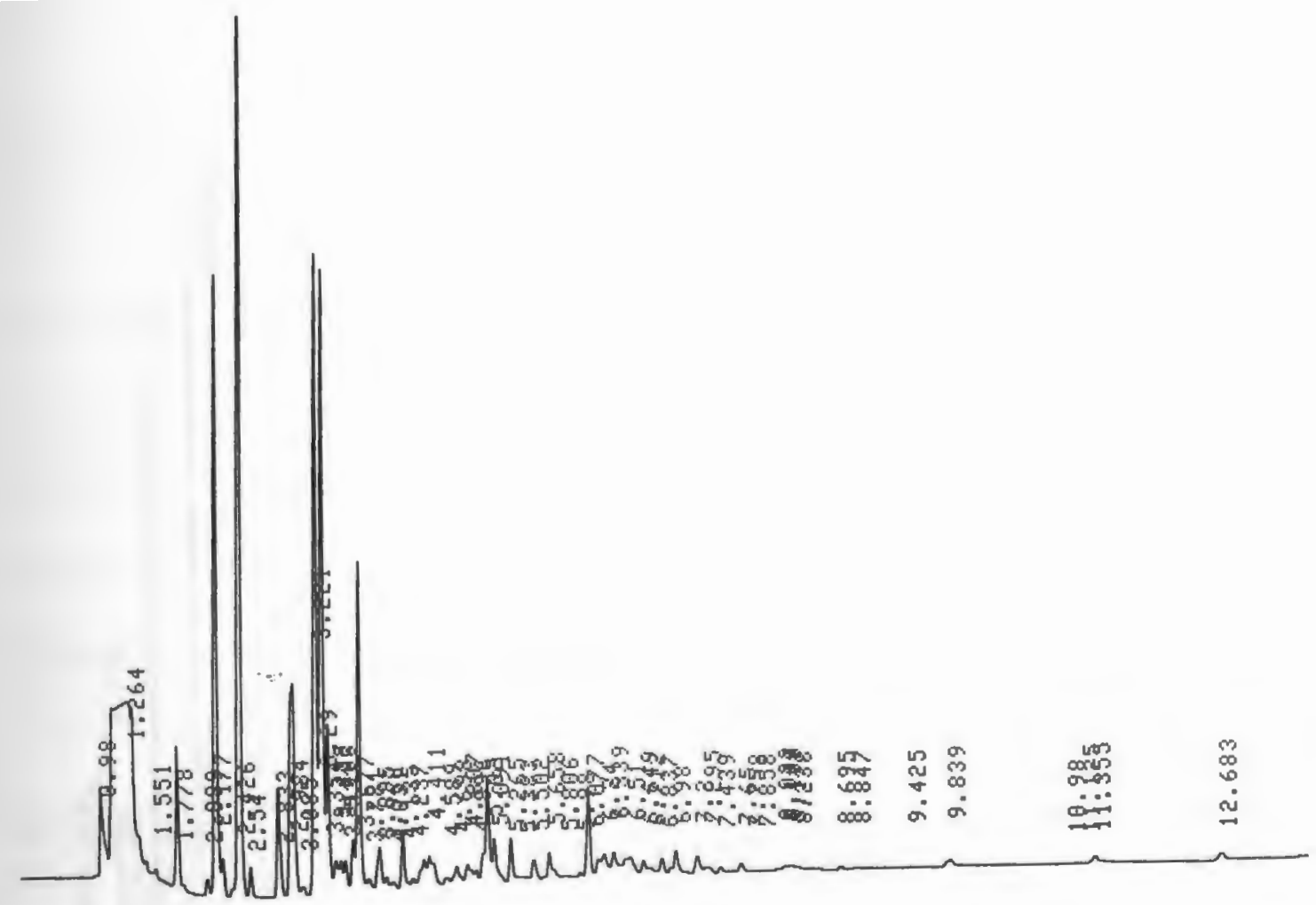

Figure 3.9- Chromatogram for $620 \mathrm{ug} / \mathrm{mL}$ of aged jet fuel (TPH) in carbon disulfide

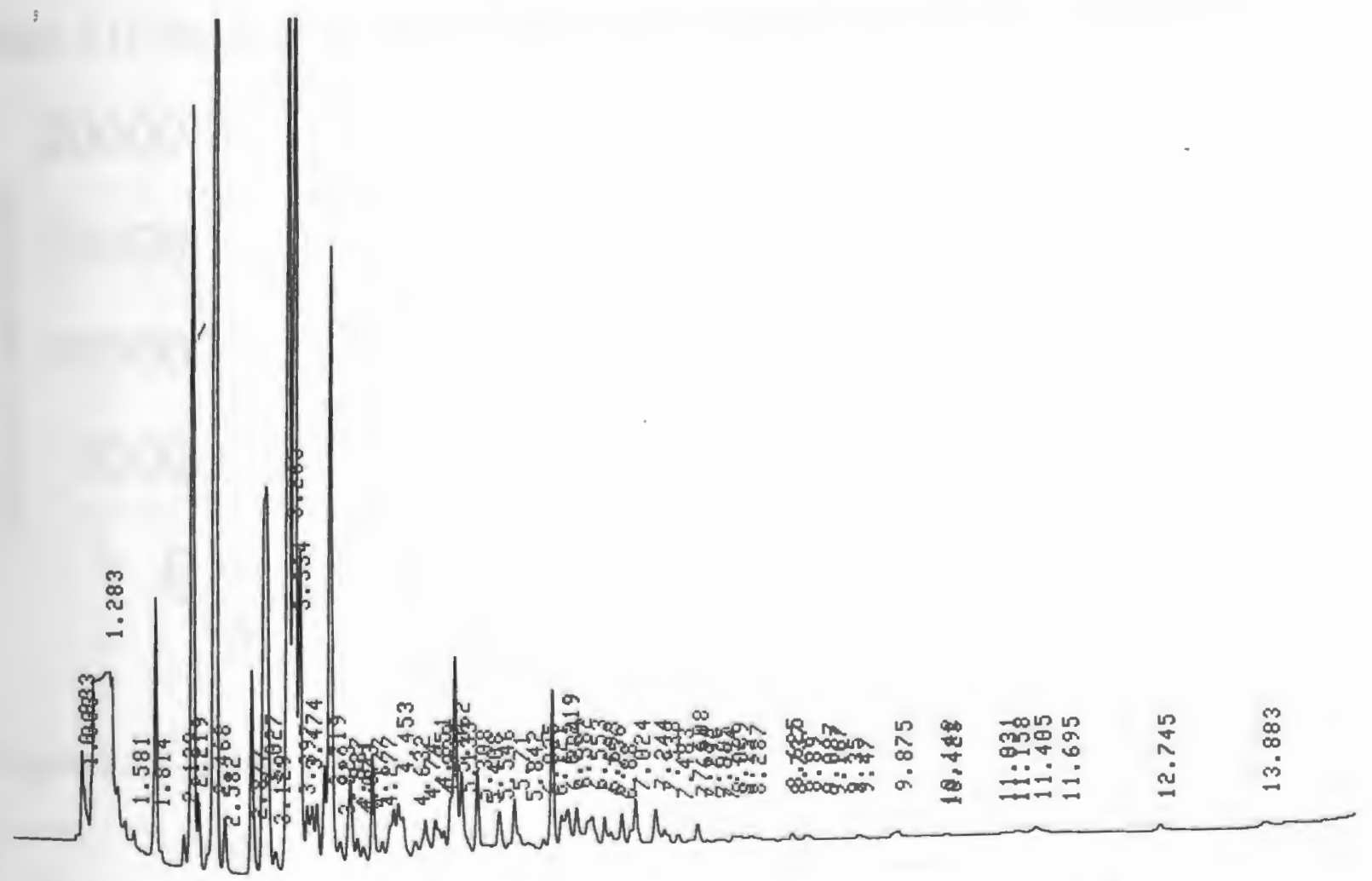

Figure 3.10- Chromatogram for $1.24 \mathrm{mg} / \mathrm{mL}$ of aged jet fuel (TPH) in carbon disulfide 


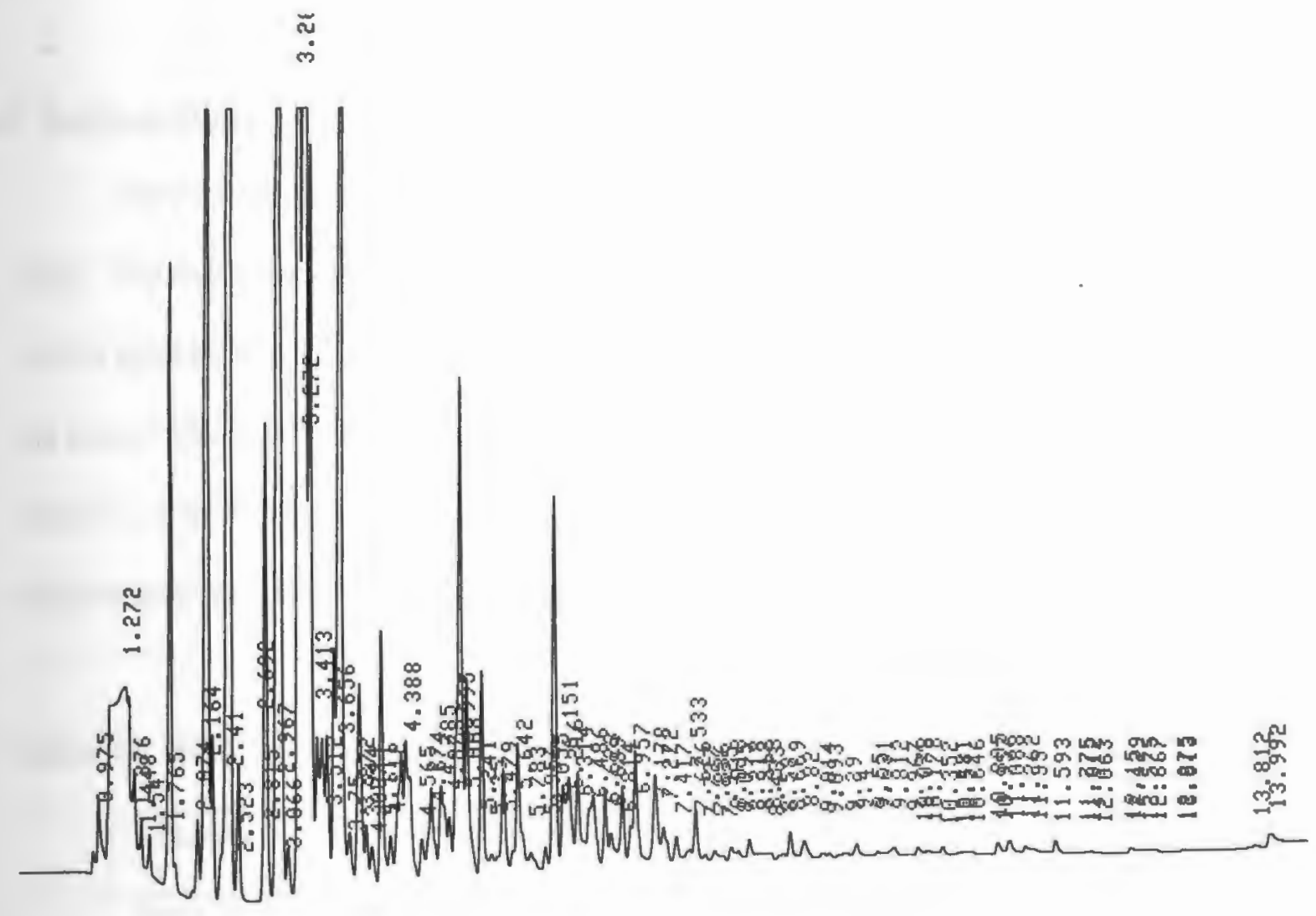

Figure 3.11- Chromatogram for $2.4 \mathrm{mg} / \mathrm{mL}$ of aged jet fuel (TPH) in carbon disulfide

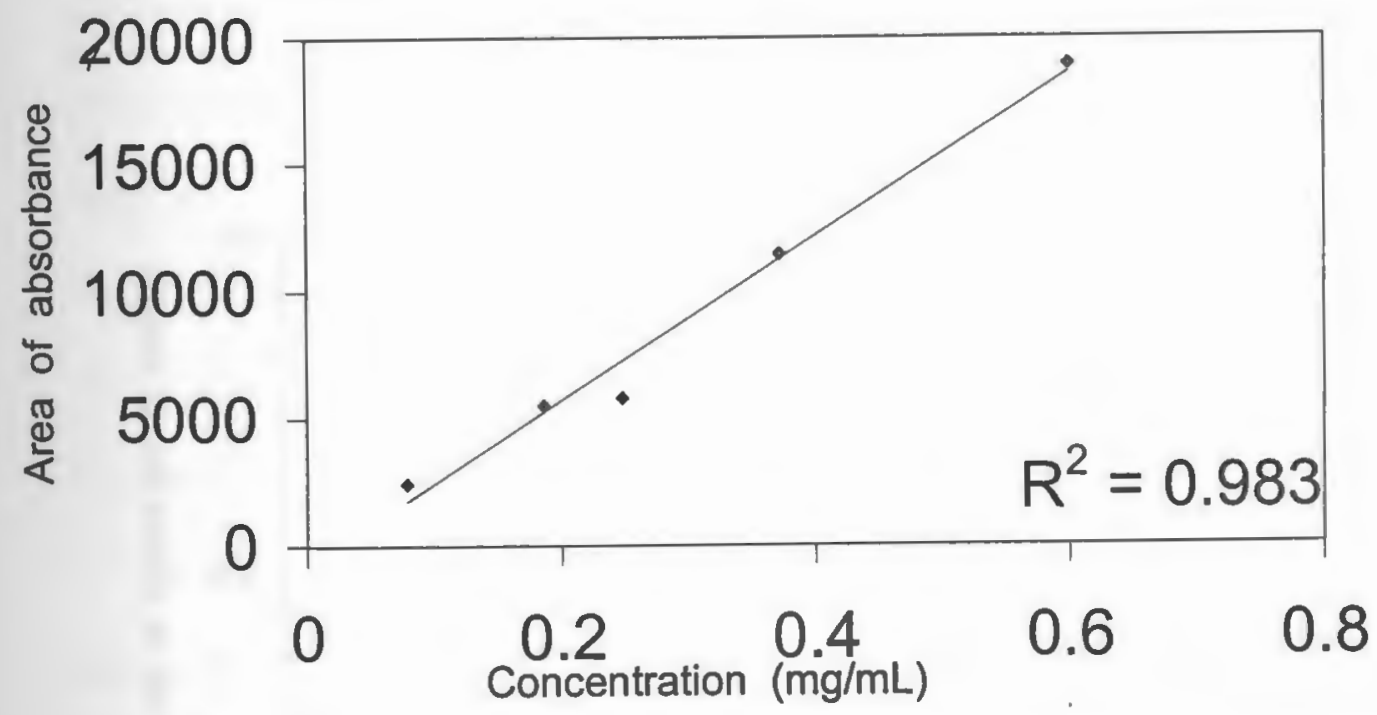

Figure 3.12 - A typical standards calibration curve used for quantifying contaminated water sample. 


\subsection{Isotherm Study}

The Fruendlich isotherm parameters $K$ and $1 / n$ were generated for the aged jet fuels. The data generated was used to determine the Freundlich isotherm parameters for the aged jet fuel/GAC. In the diagram $\mathrm{K}=\mathrm{X} / \mathrm{M}$. when $\mathrm{Ce}=1.0,1 / \mathrm{n}$ is the slope of the curve. The best fit isotherm parameters along with the $r^{2}$ values are shown in table 3.1. The $r^{2}$ which is a measure of the fit of data to isotherm, is 0.9416 . The experimental values along with the regression line is shown in Figure 3.2

Table 3.1 Best Fit Freundlich Parameters

\begin{tabular}{|c|c|l|l|l|}
\hline Sample & $\mathrm{pH}$ & $\mathrm{K}$ & $\mathrm{I} / \mathrm{n}$ & $\mathrm{r}^{2}$ \\
\hline Aged Jet Fuel/TPH & 6.8 & 0.07 & 0.324 & 0.9416 \\
\hline
\end{tabular}

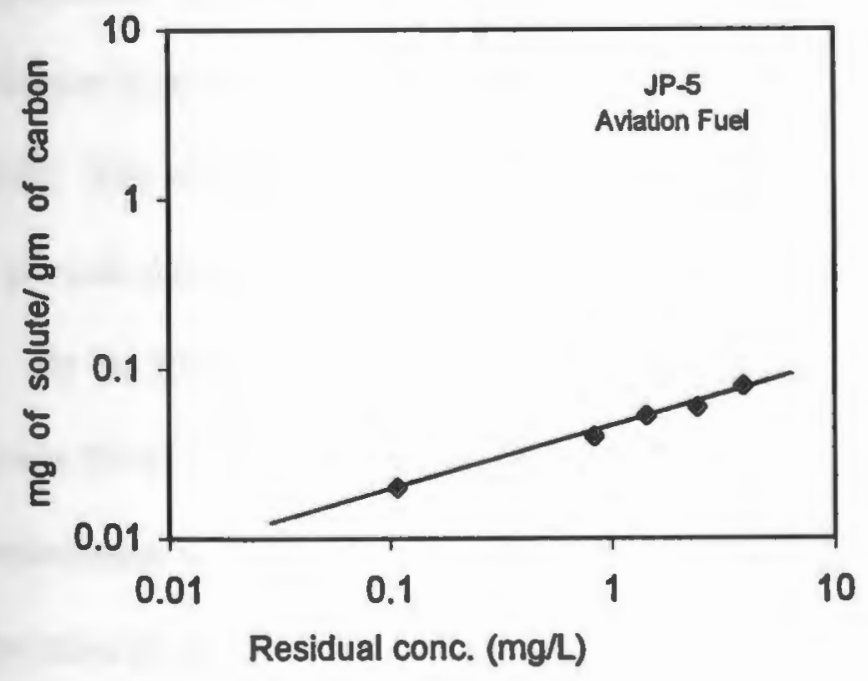

Figure 3.13- Isotherm Curve 


\subsection{GAC Column System Experiment}

The first granular activated carbon column system was operated for uninterrupted seven hours at a flowrate of $0.5 \mathrm{~L} / \mathrm{min}(0.13 \mathrm{gpm})$ and a loading rate of $2.70 \mathrm{gpm} / \mathrm{ft}^{2}$ with influent concentration of $7 \mathrm{mg} / \mathrm{L} \mathrm{TPH}$, the second experiment was at a flowrate of $0.6 \mathrm{~L} / \mathrm{min}(0.15 \mathrm{gpm})$, a loading rate of $3.25 \mathrm{gpm} / \mathrm{ft}^{2}$, influent concentration of $6 \mathrm{mg} / \mathrm{L}$ for 9 hours while the third experiment lasted for 8 hours with a flowrate of $4.04 \mathrm{gpm} / \mathrm{ft}^{2}$ with an influent concentration of $143 \mathrm{mg} / \mathrm{L}$ of aged jet fuel (TPH). The allowable breakthrough concentration for each experiment was considered to be $5 \%$ of the influent stream concentration. In other words breakthrough point was considered reached when effluent concentration was $5 \%$ of the influent concentration. The carbon bed in each of the four columns was $1.2 \mathrm{ft}$ high which yielded 3.34 minutes, 6.68 minutes, 10 minutes and 13.36 minutes cumulatively for the first experiment, 2.8 minutes, 5.6 minutes, 8.4 minutes, and 1.2 minutes in the second experiment and 2.2 minutes, 4.4 minutes, 6.6 minutes and 8.8 minutes cumulatively in the third experiment. The result of the column studies with four 3 -inch $(75 \mathrm{~mm})$ ) diameter columns in series, was summarized in Tables 3.2 -3.4 and are plotted in Figures 3.13 -3.20 . The effluent concentration, $C_{\text {out }}$ is divided by the influent concentration, $C_{i n}$, to provide the fractional breakthrough of contaminant versus time for each column.

In the first experiment, the time in column one and two where breakthrough equals $5 \%$ of the influent concentration are 2.5 hours and 7.0 hours respectively. No contaminant was detected in the third and fourth columns within the time of operation of the GAC column system. In the second experiment, only the first column reached the breakthrough point at 1.7 hours after the start of experiment. 
The first and second columns in the third experiment reached the breakthrough point at 1.8 hours and 2.5 hours respectively. The contaminant detected in the effluent of the third column in this experiment was negligible relative to the breakthrough concentration. No contaminant was detected in the fourth column.

The $\mathrm{x} / \mathrm{m}$ obtained in the column experiments are $0.67 \mathrm{mg} / \mathrm{g}, 2.6 \mathrm{mg} / \mathrm{g}$ and $20.4 \mathrm{mg} / \mathrm{g}$ for the first, second and third column respectively.

Table 3.2- Summary data at TPH breakthrough point of $0.35 \mathrm{mg} / \mathrm{L}$ using Calgon F400GAC in the first experiment with initial concentration of $7 \mathrm{mg} / \mathrm{L}$

\begin{tabular}{|c|c|c|c|c|}
\hline $\begin{array}{c}\text { Column } \\
\text { Number }\end{array}$ & $\begin{array}{c}\text { Cumulative GAC } \\
\text { depth in feet }\end{array}$ & $\begin{array}{c}\text { EBCT in } \\
\text { minutes }\end{array}$ & $\begin{array}{c}\text { Hydraulic loading } \\
\mathrm{gpm} / \mathrm{ft}^{2}\end{array}$ & $\begin{array}{c}\text { Breakthrough point } \\
\text { in hours }\end{array}$ \\
\hline 1 & 1.2 & 3.34 & 2.70 & 2.5 \\
\hline 2 & 2.4 & 6.68 & 2.70 & 6.8 \\
\hline 3 & 3.6 & 10 & 2.70 & non detected \\
\hline 4 & 4.8 & 13.4 & 2.70 & non detected \\
\hline
\end{tabular}


Table 3.3- Summary data at TPH breakthrough point of $0.3 \mathrm{mg} / \mathrm{L}$ using Calgon F$400 \mathrm{GAC}$ in the second experiment with initial concentration of $6 \mathrm{mg} / \mathrm{L}$

\begin{tabular}{|c|c|c|c|c|}
\hline $\begin{array}{c}\text { Column } \\
\text { Number }\end{array}$ & $\begin{array}{c}\text { Cumulative GAC } \\
\text { depth in feet }\end{array}$ & $\begin{array}{c}\text { EBCT in } \\
\text { minutes }\end{array}$ & $\begin{array}{c}\text { Hydraulic loading } \\
\mathrm{gpm} / \mathrm{ft}^{2}\end{array}$ & $\begin{array}{c}\text { Breakthrough point } \\
\text { in hours }\end{array}$ \\
\hline 1 & 1.2 & 2.80 & 3.25 & 1.7 \\
\hline 2 & 2.4 & 6.68 & 3.25 & non detected \\
\hline 3 & 3.6 & 8.4 & 3.25 & non detected \\
\hline 4 & 4.8 & 11.2 & 3.25 & non detected \\
\hline
\end{tabular}

Table 3.4- Summary data at TPH breakthrough point of $7.15 \mathrm{mg} / \mathrm{L}$ using Calgon F$400 \mathrm{GAC}$ in the second experiment with initial concentration of $143 \mathrm{mg} / \mathrm{L}$

\begin{tabular}{|c|c|c|c|c|}
\hline $\begin{array}{c}\text { Column } \\
\text { Number }\end{array}$ & $\begin{array}{c}\text { Cumulative GAC } \\
\text { depth in feet }\end{array}$ & $\begin{array}{c}\text { EBCT in } \\
\text { minutes }\end{array}$ & $\begin{array}{c}\text { Hydraulic loading } \\
\mathrm{gpm} / \mathrm{ft}^{2}\end{array}$ & $\begin{array}{c}\text { Breakthrough point } \\
\text { in hours }\end{array}$ \\
\hline 1 & 1.2 & 2.2 & 4.04 & 1.8 \\
\hline 2 & 2.4 & 4.4 & 4.04 & 2.5 \\
\hline 3 & 3.6 & 6.6 & 4.04 & non detected \\
\hline 4 & 4.8 & 8.8 & 4.04 & non detected \\
\hline
\end{tabular}




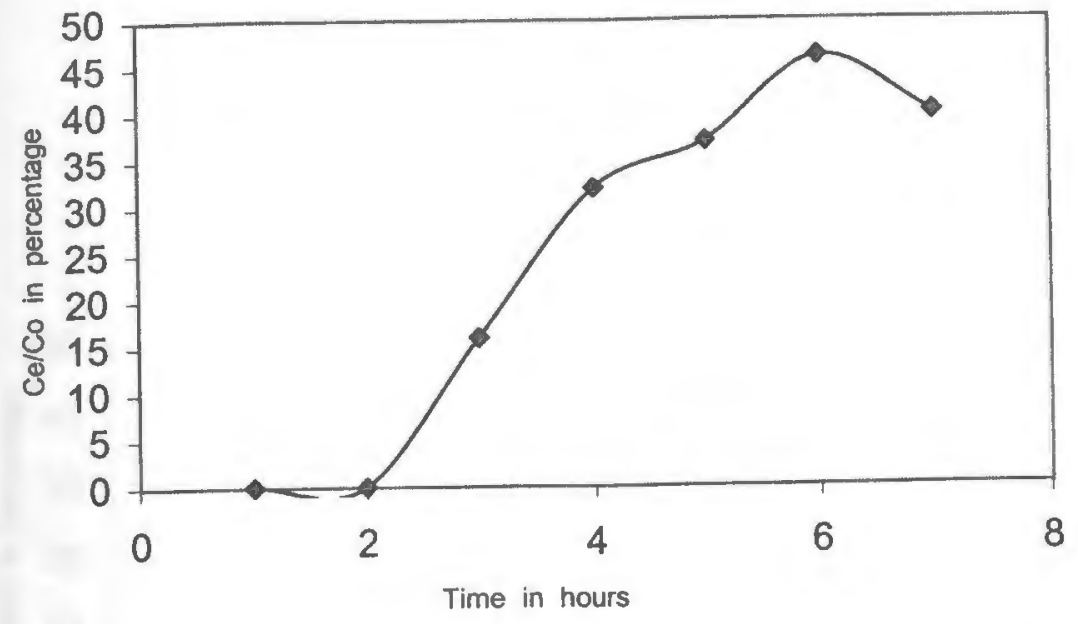

Figure 3.14- Laboratory breakthrough curve for the first filtrasorb 400 carbon column, with 3-inch diameter, $1.2 \mathrm{ft}$ deep, influent flowrate $0.5 \mathrm{~L} / \mathrm{min}$ and influent concentration of $7 \mathrm{mg} / \mathrm{L}(\mathrm{TPH})$.

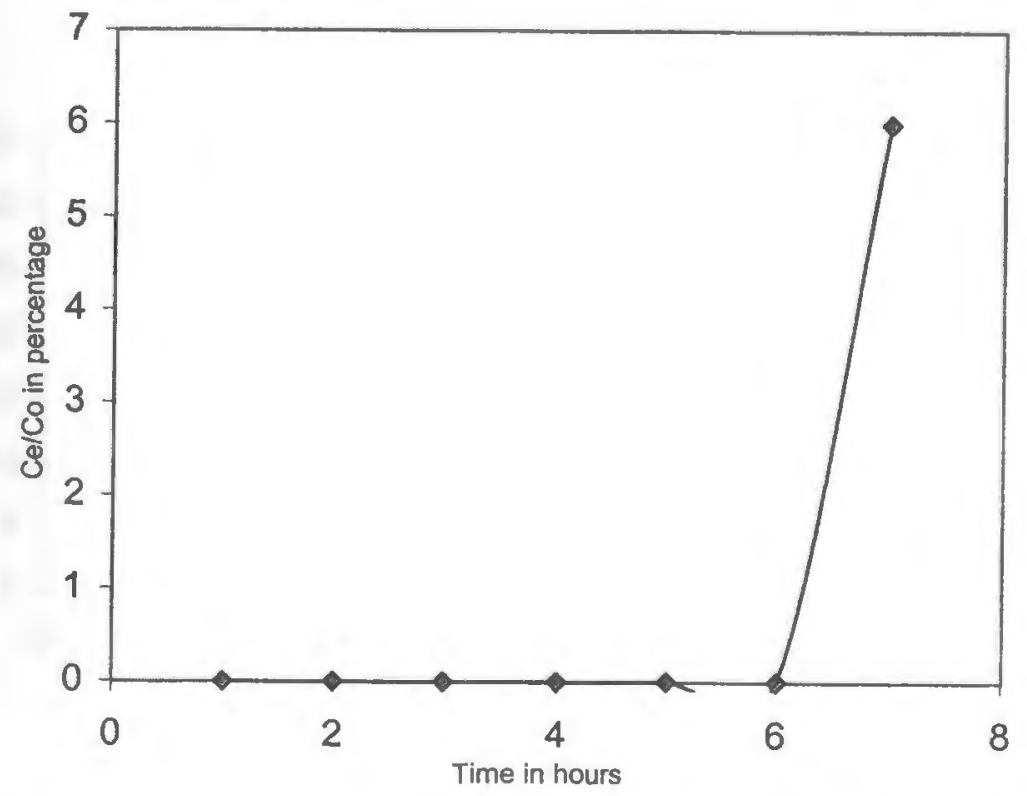

Figure 3.15- Laboratory breakthrough curve for the second filtrasorb 400 carbon column with 3 -inch diameter, $1.2 \mathrm{ft}$ deep, influent flowrate $0.5 \mathrm{~L} / \mathrm{min}$ and influent concentration of $7 \mathrm{mg} / \mathrm{L}$ (TPH) 


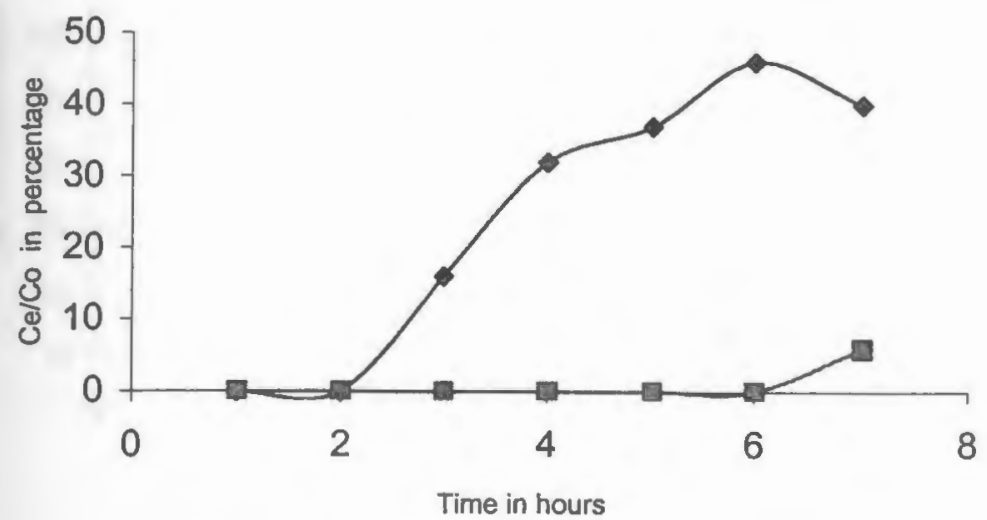

Figure 3.16- Laboratory breakthrough curve for the first and second columns above.

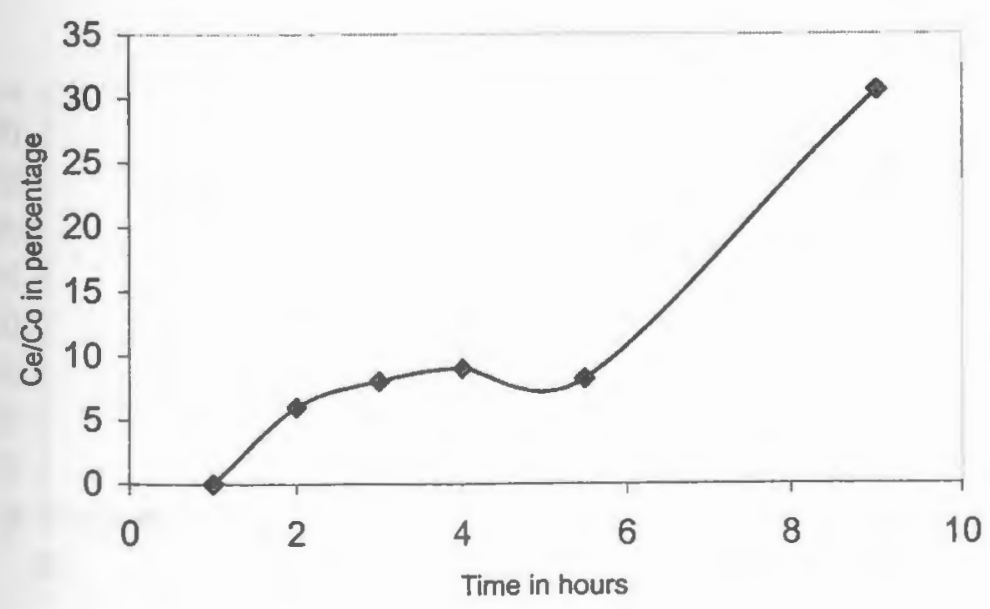

Figure 3.17- Laboratory breakthrough curve for the first filtrasorb 400 carbon column with 3 -inch diameter, $1.2 \mathrm{ft}$ deep, influent flowrate $0.6 \mathrm{~L} / \mathrm{min}$ and influent concentration of $6 \mathrm{mg} / \mathrm{L}(\mathrm{TPH})$ 


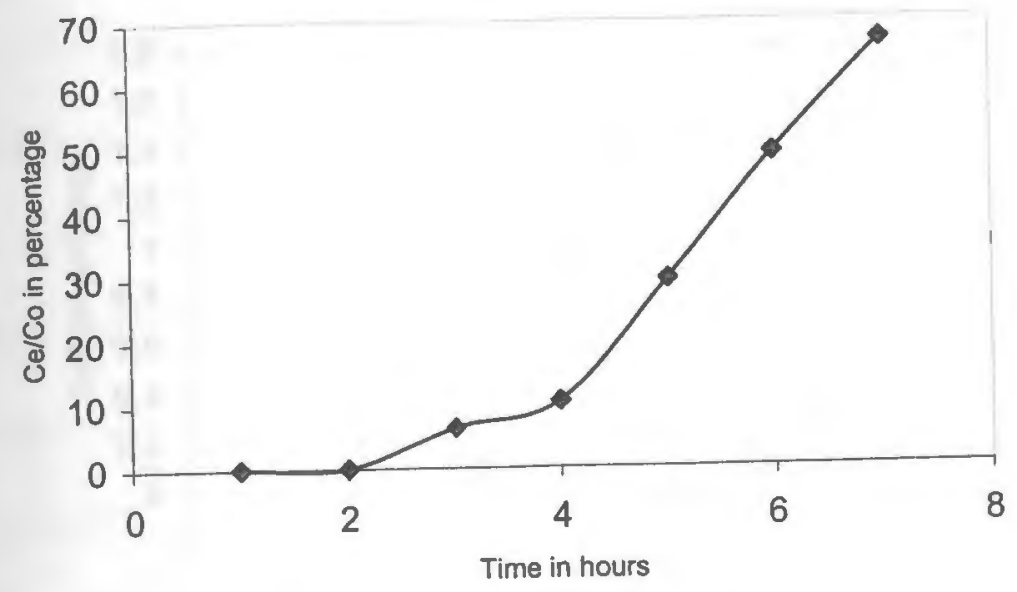

Figure 3.18- Laboratory breakthrough curve for the first filtrasorb 400 carbon column with 3 -inch diameter, $1.2 \mathrm{ft}$ deep, influent flowrate $0.75 \mathrm{~L} / \mathrm{min}$ and influent concentration of $143 \mathrm{mg} / \mathrm{L}(\mathrm{TPH})$

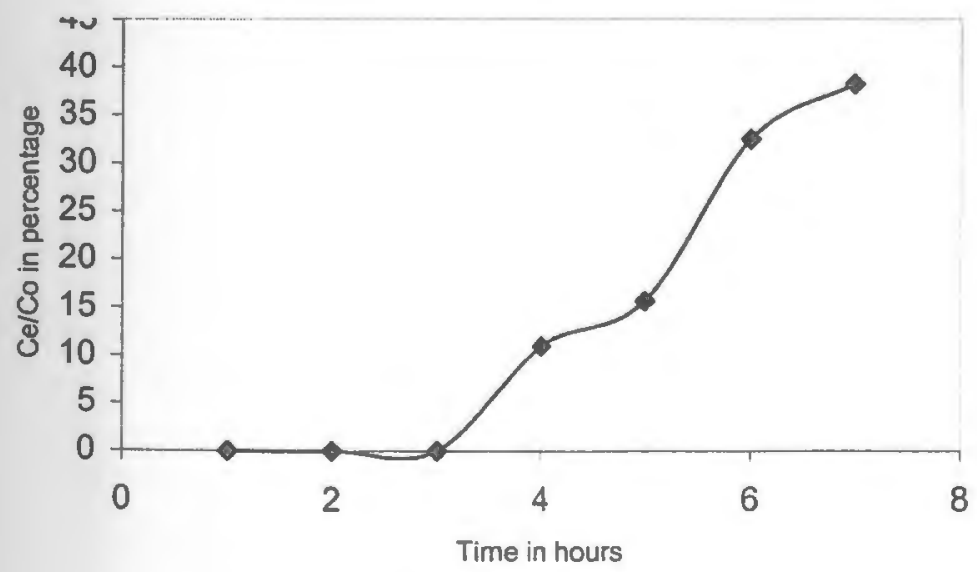

Figure 3.19- Laboratory breakthrough curve for the second filtrasorb 400 carbon column with 3 -inch diameter, $1.2 \mathrm{ft}$ deep, influent flowrate $0.75 \mathrm{~L} / \mathrm{min}$ and influent concentration of $143 \mathrm{mg} / \mathrm{L}(\mathrm{TPH})$ 


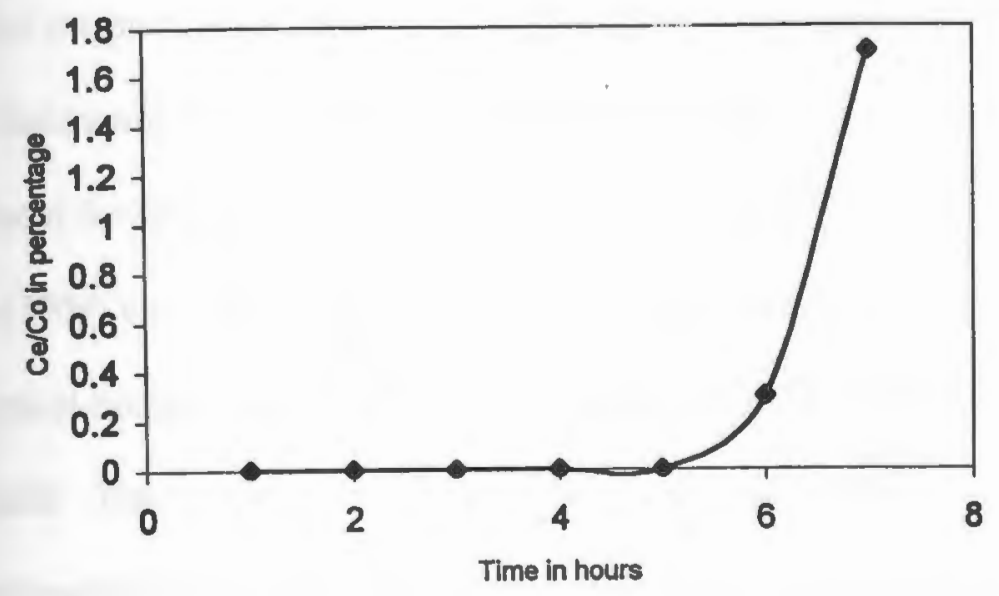

Figure 3.20- Laboratory breakthrough curve for the third filtrasorb 400 carbon column with 3 -inch diameter, $1.2 \mathrm{ft}$ deep, influent flowrate $0.75 \mathrm{~L} / \mathrm{min}$ and influent concentration of $143 \mathrm{mg} / \mathrm{L}$ (TPH) 


\subsection{Design of Field Scale Column}

For the purpose of using the Hutchins (1974) method of analysis for the design of the field scale column, the breakthrough curves for the three laboratory columns with influent flowrate $0.75 \mathrm{~L} / \mathrm{min}$ and influent concentration of $143 \mathrm{mg} / \mathrm{L}$ aged jet fuel(TPH) were projected to achieve $\mathrm{Ce} / \mathrm{Co} \%$ equals $90 \%$ and above, by simulating a typical breakthrough curve using the data obtained from the laboratory columns as a guide. The data obtained as in Figures 3.21 through Figures 3.24 which were a combination of laboratory columns data and the simulated data was used to construct the Bed-depth Service Time curve(Figure3.25). These data do not fully represent the laboratory data but give a reasonable estimate of the parameters for field scale column.

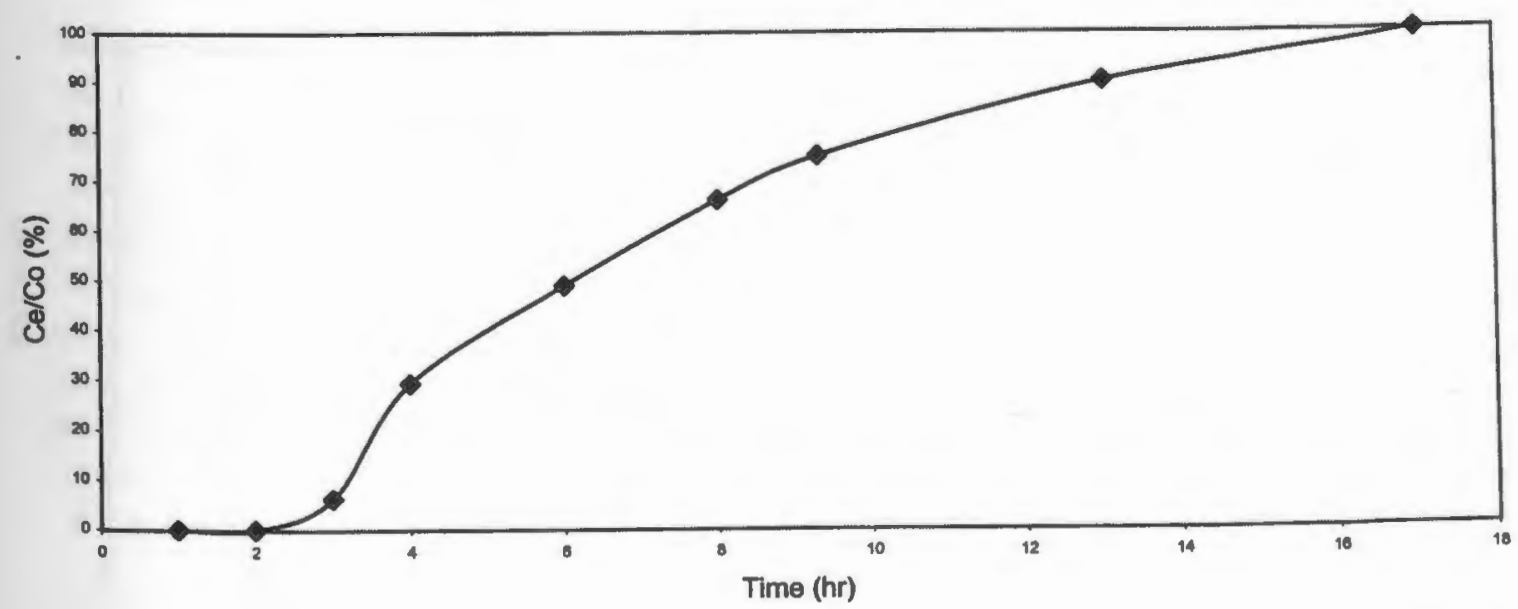

Figure 3.21-The projected/simulated breakthrough curve for first column with flowrate of $0.75 \mathrm{mg} / \mathrm{L}$ and concentration of $143 \mathrm{mg} / \mathrm{L}$. 


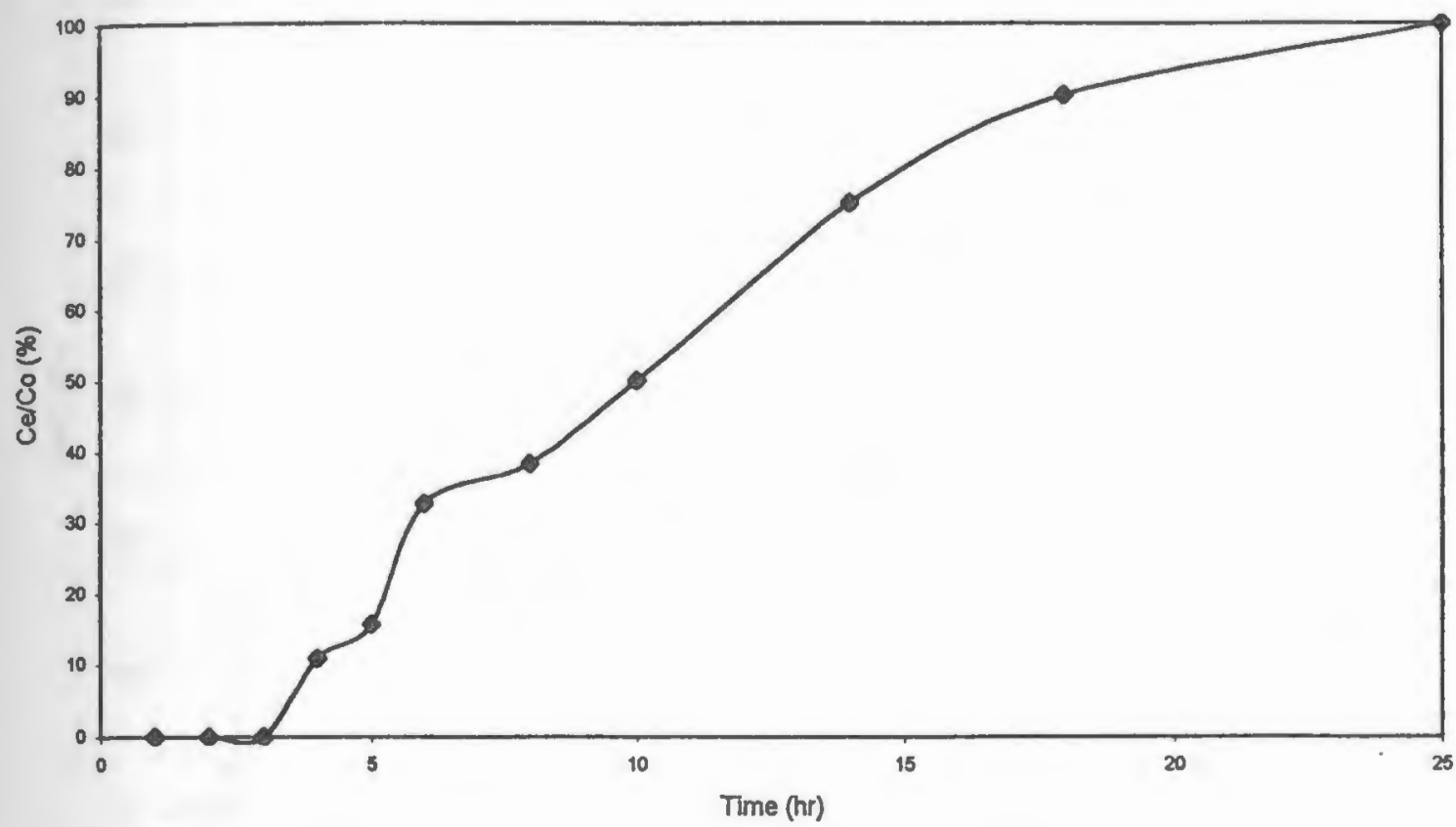

Figure 3.22-The projected/simulated breakthrough curve for second column with flowrate of $0.75 \mathrm{mg} / \mathrm{L}$ and concentration of $143 \mathrm{mg} / \mathrm{L}$.

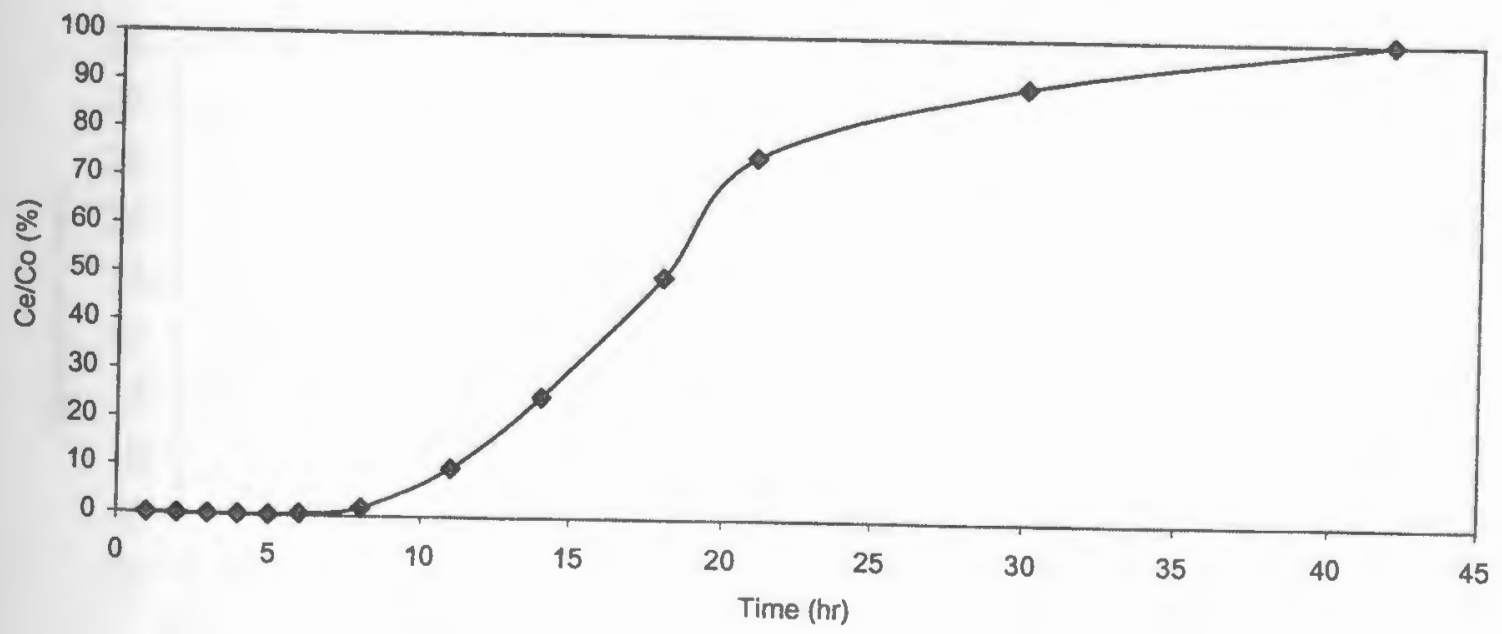

Figure 3.23-The projected/simulated breakthrough curve for third column with flowrate of $0.75 \mathrm{mg} / \mathrm{L}$ and concentration of $143 \mathrm{mg} / \mathrm{L}$. 


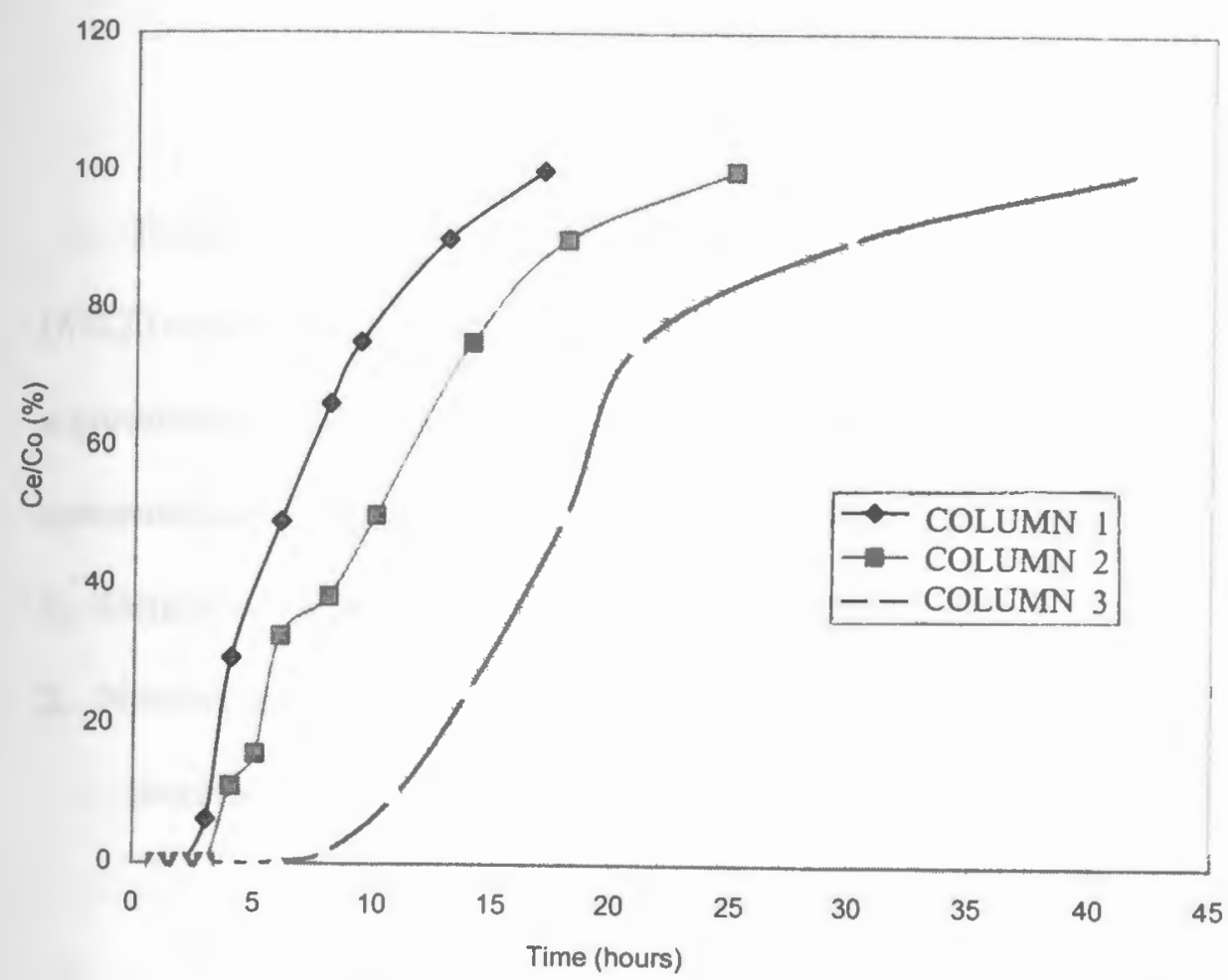

Figure 3.24-The projected/simulated breakthrough curves for three columns with flowrate of $0.75 \mathrm{mg} / \mathrm{L}$ and concentration of $143 \mathrm{mg} / \mathrm{L}$.

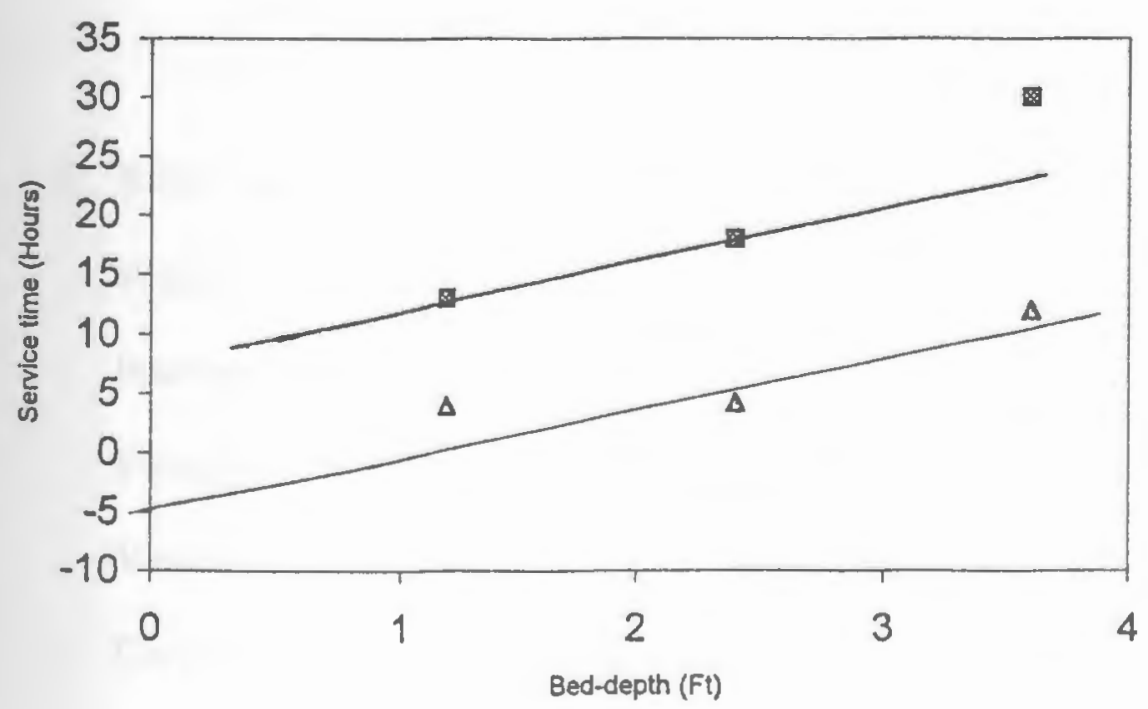

Figure 3.25-The Bed-depth Service Time curve for the three columns above 
From the Bed-depth Time Service curve(Figure 3.25), the "mass transfer zone" (MTZ) equals $2.92 \mathrm{ft}$. Using these resulting data to design a full scale GAC system for a groundwater at $50,000 \mathrm{gal} /$ day which requires to reduce aged jet fuel (TPH) concentration in the water by $90 \%$ (90\% removal) using Filtrasorb 400 as follows:

1. Height of adsorption zone (From Figure 3.25 ) $=2.92 \mathrm{ft}$

2. Number and size of units: $n=(A Z / d)+1=(2.92 / 1.2)+1=3.43$

therefore, number of units required $=4$ columns

$$
\begin{aligned}
& \text { Area of laboratory columns }=0.049 \mathrm{ft}^{2} \\
& \begin{aligned}
\text { Loading rate of lab. columns }=\mathrm{Q} / \mathrm{A} & =0.198 \mathrm{gpm} / 0.049 \mathrm{ft}^{2} \\
& =4.04 \mathrm{gpm} / \mathrm{ft}^{2}
\end{aligned}
\end{aligned}
$$

Using the same loading rate for the full scale columns yield

$$
\begin{aligned}
& \text { Area }=34.72 \mathrm{gpm} / 4.04 \mathrm{gpm} / \mathrm{ft}^{2}=8.6 \mathrm{ft}^{2} \\
& \text { Inside diameter }=(8.6 \times 4 / 1 \mathrm{~T})^{1 / 2}=3.3 \mathrm{ft}
\end{aligned}
$$

3. BDST equation for $90 \%$ removal

$$
\text { slope }=3.5 \mathrm{hr} / \mathrm{ft}
$$

Intercept,$b=-5$

Equation of line; $\mathrm{t}=3.5 \mathrm{X}-5$

Velocity of adsorption zone $=(1 / \mathrm{a})=0.3 \mathrm{ft} / \mathrm{hr}$

Carbon utilization $=$ Area $\times(1 / a) \times$ Unit weight

$$
\begin{aligned}
& =8.6 \mathrm{ft}^{2} \times 0.3 \mathrm{ft} / \mathrm{hr} \times 27.5 \mathrm{Ib} / \mathrm{ft}^{3} \\
& =71 \mathrm{Ib} / \mathrm{hr}
\end{aligned}
$$


The first experiment with influent flowrate of $0.5 \mathrm{~L} / \mathrm{min}$ and influent concentration of $7 \mathrm{mg} / \mathrm{L}$ had only the first two columns reaching breakthrough point while only the first column in the second experiment with the flowrate of $0.6 \mathrm{~L} / \mathrm{min}$ and concentration of $6 \mathrm{mg} / \mathrm{L}$ reached breakthrough point. None of the carbon in these column reached $90 \%$ exhaustion within the run time. These two columns can be used as model to design a full scale column for a contaminated groundwater at say $50,000 \mathrm{gal} /$ day, at an influent concentration of $7 \mathrm{mg} / \mathrm{L}$ by using the Formwalt et al (1966) full scale-up approach described in section 1.2.9(v). Using the data for the first experiment with influent concentration of $7 \mathrm{mg} / \mathrm{L}$,

Flow-rate $=0.5 \mathrm{~L} / \mathrm{min}=0.13 \mathrm{gpm}=0.018 \mathrm{ft} / \mathrm{min}$

Inside diameter of column $=0.25 \mathrm{ft}$, Height of carbon $=1.2 \mathrm{ft}$

Volume of one column $=0.0588 \mathrm{ft}^{3}$

Flow-rate $\left(\mathrm{Q}_{\mathrm{b}}\right)=0.018 \mathrm{ft}^{3} / 0.0588 \mathrm{ft}^{3} / \mathrm{min}=0.31 \mathrm{BV} / \mathrm{min}$

Full scale column flow-rate, $\mathrm{Q}=50,000 \mathrm{gal} / \mathrm{day}=4.64 \mathrm{ft}^{3} / \mathrm{min}$

Bed Volume (BV) for full scale column $=\mathrm{Q} / \mathrm{Q}_{\mathrm{b}}=4.64 \mathrm{ft}^{3} / \mathrm{min} / 0.31 \mathrm{~min}=15.0 \mathrm{ft}^{3}$

The mass or weight of the adsorbent $=15.0 \mathrm{ft}^{3} \times 27.5 \mathrm{Ib} / \mathrm{ft}^{3}$

$$
=412.5 \mathrm{Ib}
$$

Breakthrough occurs in the laboratory column at 2.5 hours

Breakthrough volume $\left(\mathrm{V}_{\mathrm{b}}\right)=0.5 \mathrm{~L} / \mathrm{min} \times$ gal. $/ 3.785 \mathrm{~L} \times 2.5 \mathrm{hrs} \times 60 \mathrm{~min} / \mathrm{hr}$

$$
=19.82 \mathrm{gal}
$$

The solution treated per pound of carbon $=19.82 \mathrm{gal} / 1.617 \mathrm{Ib}$

$$
=12.26 \mathrm{gal} / \mathrm{Ib}
$$


The number of pounds of carbon exhausted per hour, $M_{t}$

$$
(50,000 \mathrm{gal} / 24 \mathrm{hr})(\mathrm{Ib} / 12.26 \mathrm{gal})=170 \mathrm{Ib} / \mathrm{hr}
$$

Breakthrough time, $\mathrm{T}=\mathrm{M} / \mathrm{M}_{\mathrm{t}}$

$$
=412.51 \mathrm{Ib} / 170 \mathrm{Ib} / \mathrm{hr}=2.4 \mathrm{hrs}
$$

The breakthrough volume, $\mathrm{V}_{\mathrm{b}}$ for the field scale column

$$
\begin{aligned}
& =(50,000 \mathrm{gal} / 24 \mathrm{hr})(2.4 \mathrm{hr}) \\
& =5000 \text { gallons }
\end{aligned}
$$

Using the data for the second experiment with influent concentration of $6 \mathrm{mg} / \mathrm{L}$,

Flow-rate $=0.6 \mathrm{Lmin}=0.16 \mathrm{gpm}=0.021 \mathrm{ft} / \mathrm{min}$

Inside diameter of column $=0.25 \mathrm{ft}$, Height of carbon $=1.2 \mathrm{ft}$

Volume of one column $=0.0588 \mathrm{ft}^{3}$

Flow-rate $\left(\mathrm{Q}_{\mathrm{b}}\right)=0.021 \mathrm{ft}^{3} / 0.0588 \mathrm{ft}^{3}=0.36 \mathrm{BV} / \mathrm{min}$

Full scale column flow-rate, $\mathrm{Q}=50,000 \mathrm{gal} / \mathrm{day}=4.64 \mathrm{ft}^{3} / \mathrm{min}$

Bed Volume (BV) for full scale column $=\mathrm{Q} / \mathrm{Q}_{\mathrm{b}}=4.64 \mathrm{ft}^{3} / \mathrm{min} / 0.36 \mathrm{~min}=13.0 \mathrm{ft}^{3}$

The mass or weight of the adsorbent $=13.0 \mathrm{ft}^{3} \times 27.5 \mathrm{Ib} / \mathrm{ft}^{3}$

$$
=357.5 \mathrm{Ib}
$$

Breakthrough occurs in the laboratory column at 2.0 hours

Breakthrough volume $\left(\mathrm{V}_{\mathrm{b}}\right)=0.6 \mathrm{~L} / \mathrm{min} \times$ gal. $/ 3.785 \mathrm{~L} \times 2 \mathrm{hrs} \times 60 \mathrm{~min} / \mathrm{hr}$

$$
=19.02 \mathrm{gal}
$$

The solution treated per pound of carbon $=19.02 \mathrm{gal} / 1.617 \mathrm{Ib}$

$$
=11.76 \mathrm{gal} / \mathrm{Ib}
$$


The number of pounds of carbon exhausted per hour, $\mathbf{M}_{\mathbf{t}}$ $(50,000 \mathrm{gal} / 24 \mathrm{hr})(\mathrm{Ib} / 11.76 \mathrm{gal})=177.15 \mathrm{Ib} / \mathrm{hr}$

Breakthrough time, $\mathrm{T}=\mathrm{M} / \mathrm{M}_{\mathrm{t}}$

$$
=357.5 \mathrm{Ib} / 177.15 \mathrm{Ib} / \mathrm{hr}=2 \mathrm{hrs}
$$

The breakthrough volume, $\mathrm{V}_{\mathrm{b}}$ for the field scale column

$$
\begin{aligned}
& =(50,000 \mathrm{gal} / 24 \mathrm{hr})(2 \mathrm{hr}) \\
& =4167 \text { gallons }
\end{aligned}
$$




\subsection{CONCLUSION}

The data obtained from this study showed that an aged jet fuel contaminated water can be effectively treated by utilizing granular activated carbon columns.

Exhaustion of GAC in the multiple columns to $\mathrm{Ce} / \mathrm{Co}$ equals $90 \%$ was not accomplished, which necessitated the projection of the data obtained from columns with flowrate of $0.75 \mathrm{Liter} / \mathrm{min}$ to achieve $\mathrm{Ce} / \mathrm{Co} \%$ equals $90 \%$ and above.

The study confirmed that high influent stream concentration will require high carbon dosage, short contact time will result in early breakthrough and high exhaustion rate. Cost-effective design of a GAC system depends greatly on selection. of adsorber type and configuration, EBCT and GAC usage rate .

The fact that $\mathrm{x} / \mathrm{m}$ obtained from the batch adsorption isotherm test is negligible to that obtained from the GAC column experiments suggests that the GAC columns did not only serve as adsorber but also as a filter. This study also suggests that adsorptive capacity may depend on the initial influent stream concentration.

The Scale-up Approach method of column design requires a greater amount of activated carbon for treating the aged jet fuel contaminated water than the Bed-depth Service Time method. It should be noted that both methods require experiments with field samples and can only be used for a field scale column of like influent characteristics and concentration.

This study could be used as a model for determining the size of a field scale column for treating similar contaminants by applying the same loading rates used in this study. Also the methodology presented used in this study may be used in evaluating a laboratory column/pilot scale column for other types of contaminants and 
subsequently a field scale column for such contaminants. 


\subsection{SUGGESTIONS FOR FUTURE WORK}

Results obtained from analyses of samples from the site showed that there is considerable amount of aged jet fuel in the ground water, the use of a highly complex and highly sensitive instrument for analysis will give a more accurate contamination levels of the groundwater in the various wells.

The data obtained in this study indicated that the use of granular activated carbon column can achieve a high degree of success in remediating the jet fuel contaminated water. More attention should be geared towards a pilot scale/field scale use of GAC columns. Analysis of several breakthrough curves obtained from GAC columns arranged and operated in various configurations could give an improved and more accurate column design.

Availability of resources will encourage scholars and researchers alike and heighten interest into looking for formidable methods of remediation. 


\section{LIST OF REFERENCES}

Adams, J.Q and Clark, R.M. Evaluating the Cost of Packed-Tower Aeration and GAC for Controlling Selected Organics. Journal of American Water Works Association (Jan. 1991, 49)

Bhandari, A., Dennis C. Dove and Noval, J. T. Soil Washing and Bioremediation of

Petroleum-Contaminated Soils. Journal of Environmental Engineering (October 1994, 1151)

Buettner, M. H. and Daily W. D. Cleaning Contaminated Soil Using Electrical Heating and Air Stripping. Journal of Environmental Engineering (Aug. 1995, 580)

Clark, R. M. and Lykins B. W. jr. Granular Activated Carbon design, operations and Cost Lewis Publishers Inc. $(1989,31,83)$

Chen, P., W. Zhou and Tavlarides L.L. Remediation of Polychlorinated Biphenyl Contaminated Soils/Sediments by Supercritical Fluid Extraction. Journal of Environmental Progress Vol.16 No.3, ( Fall 1997, 227)

Choo, S. H.,Dominion C. Diguilo and Wilson, J. T. In-situ Air Injection, Soil Vacuum Extraction and Enhanced Biodegradation: A Case study in a JP-4 Jet Fuel Contaminated site. Environmental Progress ( Jan. 1997, 35)

Crittenden, J. C., David Hand, Arora Harish, James Miller and Lykin, B.W. jr. Designing Fixed-Bed Adsorber to Remove Mixture of Organics. American Water Works Association (Jan. 1989, 67) 
Donaldson, S.G., G.C. Miller and Miller W.W. Remediation of gasoline-contaminated Soil by Passive Volatilization. Journal of Environmental Quality, Vol. 21, $(1992,94)$

EPA Method 8015. Non Halogenated organics using GC/FID. Revision 2 (Dec 1996, 8015B - 1)

Formalt, H.J., and Hutchins, R.A. Purifying Liquids with Activated Carbon.

Journal of Chemical Engineering, (April:179, May:155, 1966)

Ghonasgi, D., S. Gupta, K.M. Dooley, and Knopf, F.C. Supercritical $\mathrm{CO}_{2}$

Extraction of Organic Contaminants from Aqueous Streams. AICHE J. $(1991,944)$

Hall, D. W., and Sandrin, J. A. An Overview of Solvent Extraction Treatment Technologies. Journal of Environmental Progress ( 1990, 98-104)

Heriot, David. Mobile Treatment Modules For Rhode-Island Environmental Training Center .Special Project CVE 591 Report. (1988).

Hutchins, New Method Simplifying Design of Activated Carbon System. Journal of Chemical Engineering, Vol. 80, (August 1974, 133).

Mapquest.com. Map Showing Part of North Kingstown. (1999)

Murphy,V. P. In-situ, Vacuum Assisted Steam Stripping to Remove Volatile Pollutants From Contaminated Soil. Thesis Research Submitted to Drexel University. (June 1988, 31)

Nash, J. and Traver R.P. (1988). Field Application of Pilot Soil Washing System. EPA Document No. EPA/68-03-3450. Office of Res. And Development, U.S Environ. Protection Agency, Cincinnati, Ohio. 
Osgood, J.O. Hydrocarbon Dispersion in groundwater: Significance and

Characteristics. Groundwater, Vol. 12, (1974)

Sahle-Demessie,E., Mark C. Meckes and Richardson, T.L. Remediating Pesticides

Contaminated Soils using Solvent extraction. Environmental Progress

(Winter 1996, 293)

Segall, B. A., O’Bannon, C. E. and Matthias, J.A. Electroosmotic Chemistry and Water Quality. Engrg. Div. ASCE (1980, 1148-1152)

Segall, B. A., Clifford J. Bruell and Walsh M. T. Electroosmotic Removal of

Gasoline hydrocarbons. Journal of Environmental Engineering (Feb. 1990, 68)

Seon-Hong Kang and Oulman, C. S. Member ASCE. Evaporation of Petroleum Products From Contaminated Soils. Journal of Environmental Engineering (May 1996, 384)

Smith, J.H. Final report, Department of the Airforce, National Technical Information Services, Springfield,V.A 
APPENDIX A

Individual Sample Fuel Mixture Composition Data for JP-5 
The following is JP-5 Fuel Composition as presented by Smith J.H..(1999)

\begin{tabular}{|c|c|c|c|}
\hline Cmpd Class & Carbon \# & Compound & Weight $\%$ \\
\hline Alkenes & 13 & Tridacene & $4.5 \mathrm{E}-01 \%$ \\
\hline \multirow[t]{11}{*}{ Alkyl-Monoaromatics } & 8 & m-Xylene & $1.3 \mathrm{E}-01 \%$ \\
\hline & 8 & o-Xylene & $9.0 \mathrm{E}-02 \%$ \\
\hline & 9 & 1,2,4-Trimethylbenzene & $3.7 \mathrm{E}-01 \%$ \\
\hline & 10 & 1,2,3,4-Tethramethylbenzene & $1.5 \mathrm{E}+00 \%$ \\
\hline & 10 & 1,3-Diethylbenzene & $6.1 \mathrm{E}-01 \%$ \\
\hline & 10 & 1,4-Diethylbenzene & $7.7 \mathrm{E}-01 \%$ \\
\hline & 12 & 1,2,4-Triethylbenzene & $7.2 \mathrm{E}-01 \%$ \\
\hline & 13 & 1-tert-Butyl-3,4,5-trimethylbenzene & $2.4 \mathrm{E}-01 \%$ \\
\hline & 13 & n-Heptylbenzene & $2.7 \mathrm{E}-01 \%$ \\
\hline & 14 & n-Octylbenzene & $7.8 \mathrm{E}-01 \%$ \\
\hline & 15 & 1-Ethylpropylbenzene & $1.2 \mathrm{E}+00 \%$ \\
\hline \multirow[t]{7}{*}{ Branched Alkenes } & 9 & 3-Methyloctane & $7.0 \mathrm{E}-02 \%$ \\
\hline & 10 & 2,4,6-Trimethylpentane & $7.0 \mathrm{E}-02 \%$ \\
\hline & 11 & 2-Methyldecane & $6.1 \mathrm{E}-01 \%$ \\
\hline & 11 & 4-Methyldecane & $7.8 \mathrm{E}-01 \%$ \\
\hline & 12 & 2,6-Dimethyldecane & $7.2 \mathrm{E}-02 \%$ \\
\hline & 12 & 2-Methyllundecane & $1.4 \mathrm{E}+00 \%$ \\
\hline & 13 & 2,6-Dimethylundecane & $2.0 \mathrm{E}+00 \%$ \\
\hline \multirow[t]{5}{*}{ Cycloalkanes } & 9 & 1,1.3-Trimethylcyclohexane & $5.0 \mathrm{E}-02 \%$ \\
\hline & 9 & 1,3,5-Trimethylcyclohexane & $9.0 \mathrm{E}-02 \%$ \\
\hline & 10 & n-Butylcyclohexane & $9.0 \mathrm{E}-01 \%$ \\
\hline & 12 & Phenylcyclohexane & $8.2 \mathrm{E}-01 \%$ \\
\hline & 13 & Heptycyclohexane & $9.9 \mathrm{E}-01 \%$ \\
\hline Diaromatics & 12 & Biphenyl & $7.0 \mathrm{E}-01 \%$ \\
\hline (Except naphthalene) & 8 & n-Octane & $1.2 \mathrm{E}-01 \%$ \\
\hline \multirow[t]{9}{*}{ n-Alkanes } & 9 & n-Nonane & $3.8 \mathrm{E}-01 \%$ \\
\hline & 10 & n-Decane & $1.8 \mathrm{E}+00 \%$ \\
\hline & 11 & n-Undecane & $4.0 \mathrm{E}+00 \%$ \\
\hline & 12 & n-Dodecane & $3.9 \mathrm{E}+00 \%$ \\
\hline & 13 & n-Tridecane & $3.5 \mathrm{E}+00 \%$ \\
\hline & 14 & n-Tetradecane & $2.7 \mathrm{E}+00 \%$ \\
\hline & 15 & n-Peritadecane & $1.7 \mathrm{E}+00 \%$ \\
\hline & 16 & n-Hexadecane & $1.1 \mathrm{E}+00 \%$ \\
\hline & 17 & n-Heptadecane & $1.2 \mathrm{E}-01 \%$ \\
\hline \multirow{5}{*}{ Naphthalenes } & 10 & Naphthalene & $5.7 \mathrm{E}-01 \%$ \\
\hline & 11 & 1-Methylnaphthalene & $1.4 \mathrm{E}+00 \%$ \\
\hline & 11 & 2-Methylnaphthalene & $1.4 \mathrm{E}+00 \%$ \\
\hline & 12 & 1-Ethylnaphthalene & $3.2 \mathrm{E}-01 \%$ \\
\hline & 12 & 2,3-Dimethylnaphthalene & $4.6 \mathrm{E}-01 \%$ \\
\hline
\end{tabular}




\section{APPENDIX B}

Sample Calculations 


\section{A. Sample Calculations for GAC Columns Parameters}

Diamater of Column $=3$ inches $=0.25 \mathrm{ft}$

Area of Column $=0.049 \mathrm{ft}^{2}$

Height of GAC in each column $=1.2 \mathrm{ft}$

Volume of carbon bed in 4 columns $=0.049 \mathrm{ft}^{2} \times 4 \times 1.2 \mathrm{ft}=0.2352 \mathrm{ft}^{3}$

Density of carbon GAC as supplied by manufacturers $=27.50 \mathrm{Ib} / \mathrm{ft}^{3}$

Mass of carbon in the 4 columns $=0.2352 \mathrm{ft}^{3} \times 27.50 \mathrm{Ib} / \mathrm{ft}^{3}$

$$
=6.468 \mathrm{Ib}=2940 \mathrm{~g}
$$

Mass of carbon in each column $=1.617 \mathrm{Ib}=735 \mathrm{~g}$

Flow rate $=0.5 \mathrm{Liter} / \mathrm{min}=0.132 \mathrm{gpm}=0.0176 \mathrm{cfm}$

Contact time in the first column $(\mathrm{T})=\mathrm{V} / \mathrm{Q}=\mathrm{M} / \mathrm{DQ}$

Where :

$$
\begin{aligned}
V & =\text { Volume of flow } \\
Q & =\text { rate of flow } \\
M & =\text { mass of carbon } \\
D & =\text { density of carbon } \\
T & =1.617 \mathrm{Ib} /\left(27.5 \mathrm{Ib}_{\mathrm{ft}}{ }^{3} \times 0.0176 \mathrm{ft}^{3}\right) \\
& =3.34 \text { minutes }
\end{aligned}
$$

Contact time in second column $=3.234 \mathrm{Ib} /\left(27.5 \mathrm{Ib} / \mathrm{ft}^{3} \times 0.0176 \mathrm{ft}^{3}\right\}$

$$
=6.68 \mathrm{mins}
$$

Contact time in third and fourth columns are $10 \mathrm{mins}$ and $13.34 \mathrm{mins}$ respectively.

Hydraulic Loading Rate $=\mathrm{Q} / \mathrm{A}$, 
where:

$Q=$ rate of flow

$A=$ Surface area of column

H.L.R $=0.132 \mathrm{gpm} / 0.049 \mathrm{ft}^{2}=2.70 \mathrm{gpm} / \mathrm{ft}^{3}$

\section{B. Sample Calculation For Obtaining Response Factor}

\begin{tabular}{|l|l|l|l|l|l|l|}
\hline $\begin{array}{l}\text { Elution time } \\
\text { In minutes }\end{array}$ & 1.24 & 620 & 372 & 284 & 186 & 78 \\
\hline 1.721 & 1530 & 737 & 429 & 274 & 287 & 343 \\
\hline 2.354 & 11647 & 5731 & 3435 & 2204 & 1675 & 702 \\
\hline 2.889 & 4743 & 2305 & 1381 & 879 & 665 & 269 \\
\hline 3.147 & 7659 & 3828 & 2263 & 1426 & 1114 & 449 \\
\hline 3.215 & 7403 & 3644 & 2190 & 1395 & 1023 & 410 \\
\hline 4.946 & 1954 & 939 & 544 & 315 & 108 & \\
\hline Total Area & 34936 & 17184 & 10242 & 6493 & 4872 & 2173 \\
\hline RF = C/A * & 0.000035 & 0.000036 & 0.000036 & 0.000038 & 0.000038 & 0.000035 \\
\hline
\end{tabular}

* $\mathrm{C}=$ Concentration of TPH in Carbon disulfide

$A=$ Area of Absorbance

Sample size injected into the $\mathrm{GC}=1 \mathrm{uL}$

Average Response Factor $=0.00022 / 6=0.0000367$ 
C. Sample Calculation For Quantifying Concentration of a Sample (TPH) In Solvent

where:

$$
\left(A_{s}\right)(\overline{R F})
$$

$A_{s}=$ Total areas of the peaks similar to calibration standards peaks (10979)

$(\overline{R F})=$ Mean response factor from the calibration standards

Conc. in solvent $=10979 \times 0.0000367=0.403 \mathrm{mg} / \mathrm{mL}$

D. Sample Calculation For Quantifying a Sample (TPH) in water

$$
\frac{\left(A_{s}\right)(\overline{R F})\left(V_{T}\right)}{V} \times 1000
$$

Where: $V_{T}=$ Volume of the concentrated extract $(5 \mathrm{~mL})$.

$\mathrm{V}=$ Volume of Contaminated water extracted $(250 \mathrm{~mL})$.

Conc. in water $=0.403 \mathrm{mg} / \mathrm{mL} \times 5 \mathrm{~mL} / 0.25 \mathrm{~L}=8.06 \mathrm{mg} / \mathrm{L}$

E. Sample Calculation of Obtaining Mass of Solute Per Unit Mass of Carbon

$$
\mathrm{X} / \mathrm{M}=(\mathrm{Co}-\mathrm{Ce})(\mathrm{V}) / \mathrm{Mc}
$$

where : $\quad C o=$ initial concentration of sample placed in bottle $(8.06 \mathrm{mg} / \mathrm{L})$.

$\mathrm{Ce}=$ final concentration of sample in bottle after 74 hours $(1.03 \mathrm{mg} / \mathrm{L})$.

$\mathrm{V}=$ Volume of sample placed in the bottle $(250 \mathrm{~mL})$.

$\mathrm{Mc}=$ amount of carbon placed in bottle $(20 \mathrm{~g})$.

$\mathrm{X} / \mathrm{M}=(8.06-1.03) \mathrm{mg} / \mathrm{L} \times 0.250 \mathrm{~L} / 20 \mathrm{~g}$

$$
=(7.03 \mathrm{mg} / \mathrm{L})(0.250 \mathrm{~L}) / 20 \mathrm{~g}=0.088 \mathrm{mg} / \mathrm{g}=0.09 \mathrm{mg} / \mathrm{g}
$$




\section{Experiment 1}

Fowrate $=0.5 \mathrm{~L} / \mathrm{min}$

Influent concentration $=7 \mathrm{mg} / \mathrm{L}$

First column - Mass of contaminants adsorbed by the GAC in the first column

First and second hour $=2 \mathrm{hrs} \times 7.0 \mathrm{mg} / \mathrm{L} \times 0.5 \mathrm{~L} / \mathrm{min} \times 66 \mathrm{~min} / \mathrm{hr}=420 \mathrm{mg}$

Third hour $=(7-1.05) \mathrm{mg} / \mathrm{L} \times 0.5 \mathrm{~L} / \mathrm{min} \times 60 \mathrm{~min} / \mathrm{hr}=178.5 \mathrm{mg}$

Fourth hour $=(7-2.15) \mathrm{mg} / \mathrm{L} \times 0.5 \mathrm{~L} / \mathrm{min} \times 60 \mathrm{~min} / \mathrm{hr}=145.5 \mathrm{mg}$

Fifth hour $=(7-2.45) \mathrm{mg} / \mathrm{L} \times 0.5 \mathrm{~L} / \mathrm{min} \times 60 \mathrm{~min} / \mathrm{hr}=136.5 \mathrm{mg}$

Sixth hour $=(7-3.04) \mathrm{mg} / \mathrm{L} \times 0.5 \mathrm{~L} / \mathrm{min} \times 60 \mathrm{~min} / \mathrm{hr}=118.8 \mathrm{mg}$

Seventh hour $=(7-2.67) \times 0.5 \mathrm{~L} / \mathrm{min} \times 60 \mathrm{~min} / \mathrm{hr}=129.9 \mathrm{mg}$

Total TPH adsorbed in the first column $=1129.3 \mathrm{mg}$

Second column, third hour $=1.05 \mathrm{mg} / \mathrm{L} \times 60 \mathrm{~min} / \mathrm{hr} \times 0.5 \mathrm{~L} / \mathrm{min}=31.5 \mathrm{mg}$

Fourth hour $=2.15 \mathrm{mg} / \mathrm{L} \times 60 \mathrm{~min} / \mathrm{hr} \times 0.5 \mathrm{~L} / \mathrm{min}=64.5 \mathrm{mg}$

Fifth hour $=2.45 \mathrm{mg} / \mathrm{L} \times 60 \mathrm{~min} / \mathrm{hr} \times 0.5 \mathrm{~L} / \mathrm{min}=73.5 \mathrm{mg}$

Sixth hour $=3.04 \mathrm{mg} / \mathrm{L} \times 60 \mathrm{~min} / \mathrm{hr} \times 0.5 \mathrm{~L} / \mathrm{min}=91.2 \mathrm{mg} / \mathrm{L}$

Seventh hour $=(2.67-0.41) \mathrm{mg} / \mathrm{L} \mathrm{x} 60 \mathrm{~min} /$ hour $\times 0.5 \mathrm{~L} / \mathrm{min}=67.8 \mathrm{mg}$

Total TPH in second column $=328.5 \mathrm{mg}$

Third column, seventh hour $=0.41 \times 60 \mathrm{~min} / \mathrm{hr} \times 0.5 \mathrm{~L} / \mathrm{min}=12.3 \mathrm{mg}$

Total TPH in the three columns $=(1129.2+328.5+12.3) \mathrm{mg} / \mathrm{L}=1470 \mathrm{mg}$

Each column contain $735 \mathrm{mg}$ of granular activated carbon, therefore GAC in the three

Columns $=2205 \mathrm{mg}$

$\mathrm{X} / \mathrm{M}=1470 \mathrm{mg} / 2205 \mathrm{~g}=0.67 \mathrm{mg} / \mathrm{g}$ 
F. Sample Calculation For Obtaining Freundlich Isotherm Parameters

$$
\mathrm{X} / \mathrm{M}=\mathrm{KCe}^{\mathrm{I} / \mathrm{n}}
$$

Where: $\quad \mathrm{X}=$ amount of chemical adsorbed by activated carbon (mg)

$\mathrm{M}=$ amount of adsorbent $(\mathrm{g})$

$\mathrm{K}=$ constant related to adsorption capacity

$1 / \mathrm{n}=$ constant related to adsorption intensity

$\mathrm{Ce}=$ equilibrum concentration of chemical $(\mathrm{mg} / \mathrm{L})$

From Figure 3.13, $\mathrm{X} / \mathrm{M}=\mathrm{K}$, when $\mathrm{Ce}=1.0$

$$
\begin{aligned}
& X / M=0.07 \\
& 1 / n=\text { slope }=1.1 / 3.4=0.324
\end{aligned}
$$




\section{Bibliography}

Adams, J.Q and Clark, R.M. Evaluating the Cost of Packed-Tower Aeration and GAC for Controlling Selected Organics. Journal of American Water Works Association (Jan. 1991, 49)

Bhandari, A., Dennis C. Dove and Noval, J. T. Soil Washing and Bioremediation of Petroleum-Contaminated Soils. Journal of Environmental Engineering (October 1994, 1151)

Buettner, M. H. and Daily W. D. Cleaning Contaminated Soil Using Electrical Heating and Air Stripping. Journal of Environmental Engineering (Aug. 1995, 580)

Chen, P., W. Zhou and Tavlarides, L. L. Remediation of Polychlorinated Biphenyl Contaminated Soils/Sediments by Supercritical Fluid Extraction. Journal of Environmental Progress (Fall 1997, 227)

Chen, P., W. Zhou and Tavlarides L.L. Remediation of Polychlorinated Biphenyl Contaminated Soils/Sediments by Supercritical Fluid Extraction. Journal of Environmental Progress Vol.16 No.3, ( Fall 1997, 227)

Choo, S. H.,Dominion C. Diguilo and Wilson, J. T. In-situ Air Injection, Soil Vacuum Extraction and Enhanced Biodegradation: A Case study in a JP-4 Jet Fuel Contaminated site. Environmental Progress ( Jan. 1997,35)

Clark, R. M. and Lykins B. W. jr. Granular Activated Carbon design, operations and Cost . Lewis Publishers Inc. $(1989,31,83)$ 
Crittenden, J. C., Randy D. Cortright, Brad Rick, Shin-Ru Tang and Perram, D.

Using GAC to Remove VOCs from Air Stripper off-Gas. Journal of American Water Works Association (May 1988, 73)

Crittenden, J. C., David Hand, Arora Harish, James Miller and Lykin, B.W. jr.

Design Considerations for GAC Treatment of Organic Chemicals. Journal of American Water Works Association (Jan. 19867, 74)

Crittenden, J. C., David Hand, Arora Harish, James Miller and Lykin, B.W. jr.

Designing Fixed-Bed Adsorber to Remove Mixture of Organics. Journal of American Water Works Association (Jan. 1989, 67)

Donaldson. S.G., G.C. Miller and Miller W.W., Remediation of gasoline-contaminated Soil by Passive Volatilization. Journal of Environmental Quality, Vol. 21, $(1992,94)$

EPA Method 8015. Non Halogenated organics using GC/FID. Revision 2

(Dec 1996, 8015B - 1)

Formalt. H.J., and Hutchins, R.A. Purifying Liquids with Activated Carbon. Journal of Chemical Engineering (April:179, May:155, 1966)

Ghonasgi, D., S. Gupta, K.M. Dooley, and Knopf, F.C. Supercritical $\mathrm{CO}_{2}$ Extraction of Organic Contaminants from Aqueous Streams. AICHE J.(1991, 944)

Gorod, J.F., J.P Leclerc, H. Muhr,G. Paternotter and Corrion J.P. Removing a Small Quantity of THT from Gas Storage Groundwater Through Air stripping and gas-Phase Carbon Adsorption. Journal of Environmental Progress, (Winter 1996, 277) 
Hall, D. W., and Sandrin, J. A. An Overview of Solvent Extraction Treatment

Technologies. Journal of Environmental Progress ( 1990, 98-104)

Heriot, David. Mobile Treatment Modules For Rhode-Island Environmental

Training Center. Special Project CVE 591 Report. (1988).

Hutchins, New Method and Simplified Design of Activated Carbon System.

Journal of Chemical Engineering, Vol. 80 (August 1974, 133).

Mapquest.com. Map Showing Part of North Kingstown. (1999)

Murphy,V. P. In-situ, Vacuum Assisted Steam Stripping to Remove Volatile

Pollutants From Contaminated Soil. Thesis Research Submitted to Drexel

University.(June 1988, 31)

Nash, J. and Traver R.P. (1988). Field Application of Pilot Soil Washing System.

EPA Document No. EPA/68-03-3450. Office of Res. and Development, U.S Environ. Protection Agency, Cincinnati, Ohio.

Osgood, J.O. Hydrocarbon Dispersion in groundwater: Significance and Characteristics Groundwater, Vol. 12, (1974)

Randke, S.J and Snoeyink V.L. Evaluating GAC adsorptive Capacity.

Journal of American Water Works Association (August 1983, 406)

Sahle-Demessie,E., Mark C. Meckes and Richardson, T.L. Remediating Pesticides

Contaminated Soils using Solvent extraction. Environmental Progress

(Winter 1996, 293)

Segall, B. A., Clifford J. Bruell and Walsh M. T. Electroosmotic Removal of

Gasoline hydrocarbons. Journal of Environmental Engineering (Feb. 1990, 68)

Segall, B. A., O'Bannon, C. E. and Matthias, J.A. Electroosmotic Chemistry and Water 
Quality. Engrg. Div. ASCE (1980, 1148-1152)

Seon-Hong Kang and Oulman, C. S. Member ASCE. Evaporation of Petroleum Products From Contaminated Soils. Journal of Environmental Engineering (May 1996, 384)

Smith, J.H. Individual Sample Fuel Mixture Composition Data for JP-5. Final report, Department of the Airforce, National Technical Information Services, Springfield, V.A. 